\title{
In the Name of the People: Disagreeing over Peoplehood in the North and South Korean Constitutions
}

\author{
Justine GUICHARD* \\ University of Pennsylvania
}

\begin{abstract}
As modern constitutions speak in the name of the people, they contribute to constituting the body politic by making potentially contentious claims about its members' identity, rights, and duties. Focusing on the North and South Korean Constitutions, this article examines the claims about peoplehood articulated in both texts since their concurrent adoption in 1948. The analysis argues that these claims are irreducible to the North and the South competing over two ideologically antagonistic conceptions of the body politic — a rivalry supposedly embodied in and magnified by their constitutions' use of differentiated terms to designate the people: inmin and kungmin. Instead, these categories should be seen in light of their synchronic commonalities in the North and South Korean Constitutions as well as diachronic transformations throughout the successive versions of each text, revealing that constituting the people has been less a matter of conflict between both Koreas than within each.
\end{abstract}

Keywords: constitution, peoplehood, representation, sovereignty, North Korea, South Korea

\section{INTRODUCTION}

Most modern constitutions speak, explicitly or implicitly, in the name of the people. Yet constitutions rarely are the genuine expression of popular will that they profess to be, even when the regime that they set in place is democratic. Rather than being penned by the people themselves, constitutional texts are more often written by a few (powerful political actors, rival parties, or external forces) acting on behalf of the many. ${ }^{1}$ Speaking in the people's name, however, is not just a ruse employed by constitutional framers to bind the framed"an elaborate confidence trick ... in which governing elites invent and deploy this idea of 'the people' to bolster their oligarchical arrangements of government." "Pretending to represent" does not simply involve a pretence; it also entails a pretension. ${ }^{3}$ It is in itself a political act of

* 2016-2017 Moon Family Postdoctoral Fellow in Korean Studies at the University of Pennsylvania. I would like to thank two anonymous reviewers for their stimulating comments, as well as Chulwoo Lee for his invaluable suggestions and corrections. All remaining errors are solely my own.

1. Hirschl (2009), p. 826 .

2. Loughlin \& Walker (2007), p. 3.

3. Dutoya \& Hayat (2016). 
enunciation, not primarily performed in the sense of putting on a false front, but of making a claim - a claim by constitutional framers to represent and to protect the people's interests.

"Seeing representation in terms of claims to be representative by a variety of political actors, rather than (as is normally the case) seeing it as an achieved, or potentially achievable, state of affairs as a result of election" is an approach that has been forcefully conceptualized by Michael Saward. ${ }^{4}$ Following his framework, constitutions can be said to represent the people on behalf of whom they speak not in a factual manner, but in the sense that they are made of claims about the body politic's identity, rights, and duties. The perspectival shift of Michael Saward's analysis thus leads to stress the construction at the heart of representation. Against the classical theory of representation in which the represented is "taken as unproblematically given," Saward calls for paying attention to the "subtle processes of constructing the represented, or that which needs to be represented"- - a task that, transposed in the realm of constitution making, implies nothing less than constituting the people. ${ }^{5}$

While this constructionist view is not in itself novel, going as far back as Thomas Hobbes's writings, it has been neglected by studies of representation in general, and of constitutionalism in particular. ${ }^{6}$ In the bulk of this literature, "a clearly bounded collective self called 'the people' is simply taken for granted as the starting point of discussion and not put under careful scrutiny" as pointed out by Chaihark Hahm and Sung Ho Kim in their comparison of post-1945 constitutional founding in Japan and South Korea. ${ }^{7}$ These two scholars' analysis of constitution making as a process by and through which the people constitutes itself, however, still presupposes the people's existence and agency as the constitution's author. ${ }^{8}$ Against this assumption, the people in whose name constitutions speak should be conceived as an object rather than as a subject of representation. By defining what constitutes the political community, not only through the ascription of rights and duties to its members, but also via the narration of persuasive stories that they can identify with, constitutional framers are involved in "the active making (creating, offering) of symbols or images of what is to be represented" : peoplehood itself, although this "forging ... never takes place de novo, in a state of nature." 10

Constituting the people, however, is not only a creative activity that masks its own constructedness; it is also a conflictual activity that conceals its own contentiousness. Instead of being premised on consensus, moments of constitution making and people building are likely to involve disagreement, namely competing claims about who is called—and who can

\footnotetext{
4. Saward (2006), p. 298, emphasis in original.

5. Ibid., p. 300.

6. On Hobbes's theory of representation, see Dutoya \& Hayat, supra note 3, pp. 9-10.

7. Hahm \& Kim (2015), p. 45.

8. According to Chaihark Hahm and Sung Ho Kim, "the identity of the constituent people is constituted by the choices and actions that go into the activity of exercising their constituent power. Depending on what kind of constitution it makes, the people may create different identities for itself" (ibid., p. 53).

9. Saward, supra note 4, p. 301.

10. As pointed out by Rogers Smith, "there is a crucial 'bottom-up' dimension to peoplehood .... Aspiring leaders always confront populations already endowed, individually as well as collectively, with a great variety of senses of identity and affiliation, with entrenched economic interests, political and religious convictions, historical and cultural attachments and animosities. These preexisting senses of identity, interests, and ideals are themselves partly the products of past politics of people building" (Smith, 2015, p. 42).
} 
call itself-the people. ${ }^{11}$ As we shall see, these competing claims may be both coeval with and anterior to the ones constitutions formulate, emanating not only from dissenting actors (either involved in or alienated from the drafting process), but also from predecessor documents. By speaking against these potential sources of dissonance on behalf of the entire people, namely by laying claim to the monopoly of using its voice, constitutions aim at putting an end to disagreement while drawing a veil over its occurrence. Even so, constitutions presumably remain contentious texts.

This is the case because terminating disagreement does not suffice to preclude its possibility, which, if actualized, can lead "established constitutional forms" to be "challenged and resisted, marginalized, and undermined, and even surpassed and overcome." 12 More subtly, terminating disagreement does not suffice to erase its discursive signs or traces, which may not only be recorded in but also excavated from constitutions thanks to an interpretive reading of them. Analyzing constitutions as texts in which certain claims about the people are articulated while others are silenced opens up the possibility for a more politically complex and dynamic approach to fundamental norms than is offered through literal lenses. ${ }^{13}$

In the case of the two Koreas that this article examines and compares, constitution making seems intimately tied to claim making — and quieting — in the context of the dispute that has opposed the Democratic People's Republic of Korea (DPRK, or North Korea) and the Republic of Korea (ROK, or South Korea) since their founding in 1948. For decades, each state pretended to be the only one legitimately representing the whole people across the divided peninsula and along antagonistic ideological lines. From this perspective, the North and South Korean Constitutions appear to be the product of an extreme case of disagreement on peoplehood, one in which two actors' conflict over popular representation is compounded with a conflict over political orthodoxy and territorial sovereignty.

Yet the claims made in both texts are irreducible to the two Koreas competing over representing the people - a rivalry supposedly embodied in and magnified by their constitutions' use of differentiated terms to designate the body politic: inmin in the North and kungmin in the South. ${ }^{14}$ Far from being exclusively constructed in contradistinction to each other, inmin and kungmin have also taken shape on their own, before as well as after the 1945 de facto division of the Korean peninsula. If the antinomy of both categories fully imposed itself with the 1948 de jure establishment of two polities north and south of the 38th parallel, inmin and kungmin have always been articulated in reference to intra-Korean-rather than just inter-Korean-imperatives and conflicts.

11. As defined by Jacques Rancière, "the structures proper to disagreement are those in which discussion of an argument comes down to a dispute over the object of the discussion and over the capacity of those who are making an object of it." See Rancière (1999), p. xii.

12. Loughlin \& Walker, supra note 2, p. 4.

13. According to the definition proposed by Rogers Smith, who conceptualizes the politics of people building as not being limited to nation-states, political peoples are "any and all human associations, groups, and communities that are commonly understood to assert that their members owe them a measure of allegiance against the demands of other associations, communities, and groups" (Smith, supra note 10, p. 2). To Smith, this competition is precisely what makes "political peoplehood" political (ibid., p. 39).

14. This article relies on the McCune-Reischauer system of romanization to transliterate Korean words and names (except those of scholars, kept as reflected in their English publications, as well as Seoul and Pyongyang). When the name of a historical figure is more commonly known with a divergent orthography, the McCune-Reischauer version is indicated in parentheses upon the name's first occurrence only. 
In this sense, the DPRK and ROK Constitutions no longer appear as atypical texts premised on an extreme form of disagreement between two states. Each is instead symptomatic of internal dynamics of political inclusion and exclusion that potentially operate in all moments of constitutional (re)founding, when the people's identity, entitlements, and responsibilities become defined against alternate possibilities. ${ }^{15}$ The claims that constitutions offer, and by extension those that they dismiss, are usually believed to assume two distinguishable forms: on the one hand, declaratory, aspirational principles; on the other hand, operative, enforceable rules, at least in appearance (indeed, even constitutions whose norms fail to be binding tend to profess their efficacy). Such a "hard" boundary between political and legal languages, however, may prove more difficult to trace than suggested by the structure of constitutional documents itself, in which preambulatory and/or introductory clauses are set apart from institutional arrangements as well as individual rights and duties provisions.

Adhering to this formal divide between a constitution's different parts tends to mask how the claims about peoplehood that run throughout its text are intertwined, producing more extensive performative effects when read in conjunction rather than in isolation. Opening statements of a declarative, narrative, and generic character can therefore (be) shed unexpected light upon (by) seemingly unrelated propositions, such as the economic organization of society. Yet the analysis of constitutional language adopted in this article is not only synoptic, but also sequential. Contrasting successive versions of a given constitution, evenor especially — when considered to be no more than a "façade," makes legible in previously unseen ways how (re)drawing the contours of the political community entails to outspeak alternative voices. $^{16}$

In light of the synchronic and diachronic conflictuality embedded in the task of instituting and circumscribing the body politic, this article contends that the issue of constituting the people has been at stake not only between both Koreas, but also, and perhaps more importantly, within each. Its first part further argues that the inter-Korean disagreement over whom "the people" is and who can speak in its name may thus deserve to be relativized, both in the 1948 Constitutions and as the two original texts were subsequently revised. The second part of the analysis explores how the corresponding intra-Korean dispute over peoplehood has, on the contrary, intensified, particularly in the context of the North's authoritarian radicalization, fully completed by the early 1970s, and of the South's transition to democracy, set in motion in the late 1980s.

\footnotetext{
15. In this context, according to Jon Elster, "we should not be surprised that constitution making goes together with violence. According to a cliché to which I have unfortunately contributed (Elster 1984, ch. II.7), constitutions are typically written in a calm and reflective moment that enables sober and public-spirited framers to design institutions that will prevent the interests and passions of future actors from acting against the general interest. The reality is different" (Elster, 2012, p. 8).

16. As underlined by Tom Ginsburg and Alberto Simpser, "there is great utility in longitudinal analysis of constitutional sequences in individual countries," especially in cases of authoritarian revision and/or amendment when "the sequence of documents will provide clues over the particular leaders' political concerns and predilections" (Ginsburg \& Simpser, 2014, p. 15). While the Constitution of North Korea is commonly described as a "pure sham," Yi Yŏng-nok has relied on the typology established by German political scientist Karl Loewenstein to similarly characterize the South Korean Constitution as "nominal" or "decorative" until at least the country's 1987 transition to democracy (Yi, 2006, p. 7).
} 


\section{WHOM “THE PEOPLE” IS: AN INTER-KOREAN (DIS)AGREEMENT}

In 1948, the constitutional founding of two Korean states north and south of the 38th parallel did not merely transform a de facto situation (the 1945 division of the peninsula) into a de jure one. Their establishment amounted to more than a procedural formality and formalization of existing arrangements. The process of instituting two separate states and constitutions appeared openly contentious since each negated the other's sovereignty and legitimacy, as encapsulated in both documents' territorial clauses. On the one hand, Article 4 of the 1948 Constitution of the ROK (taehan min'guk hŏnpŏp) defined its territory (yŏngt'o) as encompassing the entire peninsula (hanbando) and its adjacent islands (pusok tosŏ) rather than the southern half only. ${ }^{17}$ On the other hand, Article 103 of the 1948 Constitution of the DPRK (chosŏn minjujuŭi inmin konghwaguk hŏnpŏp) identified Seoul instead of Pyongyang as its capital (subu). ${ }^{18}$ Furthermore, the two texts deployed distinct terms to designate not only Korea (taehan min'guk/chosŏn), but also the people that they claimed to represent (kungmin/inmin). Such dissonance is usually believed to manifest and magnify the inter-Korean disagreement over whom the people is and who can speak in its name. This conventional account, however, will be interrogated in this article's first part, which highlights convergences in how the North and South Korean Constitutions construct both political peoplehood (as an object of mobilization rather than as a subject of sovereignty) and the national division (by accepting rather than negating its institutional reality).

\subsection{Inmin versus Kungmin: Two Visions of Peoplehood or One Vision of Two Peoples?}

North and South Koreas resort to different vocables to denominate the people (inmin/ kungmin) but not to the nation (minjok). This lexical phenomenon is ordinarily interpreted as signifying their consensus on peoplehood as national identity but dissensus over peoplehood as a political project. In other words, there would exist an inter-Korean agreement over the boundaries of the national community, defined in terms of ethnic homogeneity, but an interKorean disagreement over the contours of the political community, given the antagonistic ideological lines through which these contours are drawn in the North and in the South. The following two sections raise the question of what the apparent inter-Korean disagreement over naming the body politic says about each state's vision of peoplehood. The analysis first nuances the opposition between inmin and kungmin in light of the pre-1945 fluidity of their uses before arguing that their deployment even after liberation may have entailed more commonality than is conventionally assumed.

17. ROK (1948). All subsequent quotations from the 1948 Constitution of the ROK come from this source. The original Korean version of the ROK Constitution and its subsequent amendments are accessible on the website of the South Korean Ministry of Government Legislation (MOLEG)'s National Law Information Centre (kukka pŏmnyŏng chŏngbo sent’ŏ), online <http://www.law.go.kr/lsSc.do?menuId=0\&subMenu=2\&query=대한민국헌법> (last accessed 8 April 2016).

18. DPRK (1948). All subsequent quotations from the 1948 Constitution of the DPRK come from this source. The original Korean version of the DPRK Constitution and its subsequent amendments are accessible on the website of the MOLEG's North Korea Laws Information Centre (pukhan pŏpche chŏngbo sent’ŏ), online < http://world.moleg.go.kr/ $\mathrm{KP} / \mathrm{law} / 23273$ ?astSeq $=582>$ (last accessed 8 April 2016). 


\subsubsection{Neither Antagonism nor Amalgamation of Inmin and Kungmin before 1945}

The current ideological antagonism of inmin and kungmin is not ingrained in these two terms. At the turn of the twentieth century, the prime divide between them was a historical one, the novelty of kungmin contrasting with the antecedence of inmin, one of the traditional vocables to designate the people. ${ }^{19}$ In those years when the peninsula found itself "between Empires," increasingly a target of rivalry between the regional ambitions of Russia and the rising power of Japan, the efforts that were undertaken to defend Korea's independence ignited intense public discussions about its sovereignty. ${ }^{20}$ In this context, the idea of peoplehood was particularly deployed and reframed by a reformist (and mainly Christian) elite desirous of politically modernizing Korea but hesitant about the role to be played by the uneducated masses in the advent of such a transformation.

These intellectuals' ideas were most prominently exposed from 1896 to 1899 in The Independent (tongnip sinmun), the first newspaper published in vernacular Korean language (hangŭl) rather than classical Chinese characters "to enable men and women of all social classes to read" and be informed about "what the government does." ${ }^{21}$ Founded and edited by Sŏ Chae-p’il (1864-1951, also known by his anglicized name Philip Jaisohn), The Independent "played a central role in articulating the novel idea of citizenship by recasting ordinary Korean people who used to be, at best, the object of benevolent rule"22.

While it continued to use such old terms as paeksŏng or inmin (ordinary people who were ruled), mostly to refer to members of the state to be modernized (Ryu 2004: 55), [The Independent] redefined them as right-bearing and equal members - at least in abstract terms. ... At the same time, civil rights and political rights were clearly circumscribed in the discourse of citizenship in the newspaper, because the people were presumably not ready for these rights. ... Although they were entitled to some political rights - which was indeed a radical idea at the time- -their citizenship was marked by a duty to be useful to the nation and follow enlightened leaders. ... In this framework, the people's rights and equality were necessary not because they would foster independent individuals, but rather because they would strengthen the nation. It is no accident that the old collectivist terms, paeksŏng and inmin, were used most frequently to refer to new members of the nation-state, while such terms as "individual" or "citizen" were altogether absent in the discourse. ${ }^{23}$

The understanding of peoplehood that emerged in those years under the pen of future first South Korean president Rhee Syngman (Yi Sŭng-man, 1875-1965) further illustrates some of the ambivalences embedded in the early independence movement's conception of citizenship. In Rhee's writings, particularly his Spirit of Independence (tongnip chŏngsin), prepared while he was imprisoned between 1899 and 1904, "the category of paeksong still retained that character of requiring edification (hwa)" since "[Rhee] thought the Korean people were not up to the task of defending Korea's independence, and his view, as reflected in his political practice, hardly changed. ${ }^{, 24}$ As we shall see, the fear that the people might not be ready for the full exercise of its political agency permeates discourses articulated not only during the early independence movement, but also in the wake of the anti-colonial struggle of

\footnotetext{
19. Pak (2009), p. 85.

20. Schmid (2002).

21. Lee et al. (1996), p. 389.

22. Moon (2013), pp. 11-12.

23. Ibid., p. 12.

24. Em (2013), pp. 73-4.
} 
1 March 1919 (samil undong), following which the Provisional Government of the Republic of Korea (taehan min'guk imsi chŏngbu) was founded in exile and drafted several texts, including two provisional constitutions, reflecting this concern.

In the meantime, new categories emerged alongside old ones to speak of, and for, the people. While paeksŏng and inmin were prevalent in The Independent's articles and debates (with the former being more recurrent than the latter), less visible terms bound to later prevail included "tongp'o (those who share umbilical cords) as well as kungmin (national or state's people)." 25 On the one hand, the initial infrequency of racial or ethnic categories such as tongp'o has led several authors to highlight "the presence of civic and universalistic approaches to nation building" in these formative years of the late nineteenth century, "challeng[ing] the conventional view that treats the current conflation of nation, ethnicity, and race as inevitable or natural" in the case of Korea. ${ }^{26}$ On the other hand, a new term such as kungmin shifted from discursive marginality to prominence in the span of two decades.

Having appeared in the 1890s as a translation of the Japanese kokumin (itself a translation of the German Staatsvolk), kungmin had become the privileged vocable to name and theorize the modern body politic by the 1910s. In Japanese as well as in Korean, its emphasis was primarily laid on people (min)'s subordinated relationship to the state (respectively kokka and kukka), neither conveying a vision of the people as bearers of political rights (which, although limited, were part of the early independence movement's discourse about paeksŏng and inmin) nor implying, originally, an ethnic conception of the nation (a connotation already underlying the German notion of Staatsvolk that the Japanese and Korean language of nationalism would soon acquire with the experience of colonial rule). ${ }^{27}$

With Korea's annexation by Japan in 1910, "the Japanese notion of the self-sacrificing kungmin loyal to the emperor became the model to shape the colonized Koreans" according to Seungsook Moon. ${ }^{28}$ As a result, "colonial rule not only relegated Koreans to second-class membership of the Japanese empire, it also facilitated the spread of the authoritarian view of citizenship previously adopted through the discourse of kungmin." 29 In light of its articulation by colonial authorities as well as later appropriation by a number of Korean intellectuals sharing their project of cultural assimilation, kungmin's absence from the 1 March 1919 Declaration of Independence (3.1 tongnip sŏnŏnsŏ) could be read as a reaction against and rejection of the subjection of peoplehood implied by the term. ${ }^{30}$ This text, which was “quickly drafted by Ch'oe Namsŏn [1890-1957], and thirty three 'representatives of the Korean people' (sixteen Christians, fifteen leaders of Ch'ŏndogyo [an indigenous religious movement], and two Buddhists),"31 opened with the proclamation that "We hereby declare

\footnotetext{
25. Moon, supra note 22, p. 31.

26. Shin (2006), p. 118.

27. Moon, supra note 22, p. 13-14.

28. Ibid., p. 15 .

29. Ibid.

30. The Korean version of the 1 March 1919 Declaration of Independence is accessible online at < https://ko. wikisource.org/wiki/3·1독립선언서> (last accessed 7 April 2016). An English translation can be found in Provisional Government of the Republic of Korea (1919b).
}

31. Ibid., p. 430. 
that Korea (chosŏn) is an independent state (tongnipguk) and that Koreans (chosŏnin) are a self-governing people (chajumin)." Apart from these expressions, the dominant ones to refer to the people throughout the declaration were minjok and minjung but never kungmin.

Yet, as revealed by the various provisional constitutions adopted by the Republic of Korea founded in Shanghai after the repression of the 1 March 1919 movement, so clear a line of separation between the discourse of colonial authorities and Korean independence groups cannot be easily drawn. Out of the six constitutional texts written by the provisional government between 1919 and 1944, kungmin was mentioned several times in two of them, respectively from 11 April 1919 (taehan min'guk imsi hŏnjang) and 9 October 1940 (taehan min'guk imsi yakhŏn). ${ }^{32}$ Even in these instances, however, it was used alongside inmin, which overall appeared as the favoured word to designate the people. Consisting of a preamble and ten articles, the Provisional Constitution of 11 April 1919 thus consecrated in its Article 3 the equality of the new republic's people (inmin), regardless of sex, class, and occupation-three markers that had organized the stratification of society under the Chosŏn dynasty (1392-1910). Inmin was moreover the only term present in the constitutional proposals of 11 September 1919 (taehan min'guk imsi hŏnjang), 7 April 1925 (taehan min'guk imsi hŏnpŏp), 5 March 1927 (taehan min'guk imsi yakhŏn), and 22 April 1944 (taehan min'guk imsi hŏnjang).

Except in the 9 October 1940 text, where national sovereignty (chukwŏn) was recognized to kungmin, the provisional government attributed it to inmin in September 1919 and April 1944, with the other documents not containing sovereignty clauses per se. ${ }^{33}$ This points to the ideological neutrality attached to inmin in terms of right-left divide during the colonial period. Although initially composed of "men of diverse social and ideological backgrounds," 34 the provisional government tended to represent the conservative branch among the different Korean independence organizations operating abroad, which were dominated by the left in general, and Communists in particular after the 1930s. Having survived various changes of leadership, the republic in exile was most famously presided over by Rhee Syngman from 1919 to 1925 , when he was reportedly impeached by the provisional assembly, and later headed by Kim Ku (1876-1949), another right-wing nationalist, from 1940 to $1947 .^{35}$

In its early years, the provisional government's construction of peoplehood continued to be influenced by some of the ideas evoked about the independence movement of the late nineteenth century. The notion that the people was unfit for political sovereignty while being recognized as the source from which power emanated materialized in the "Aims and Aspirations of the New Korean Republic" released by the provisional government after the mass demonstrations of 1 March 1919:

(1) We believe in government which derives its just power from the governed. Therefore, the government must be conducted for the interest of the people it governs.

32. Original Korean versions of the Provisional Government of the Republic of Korea's constitutional texts are accessible on the website of the MOLEG's National Law Information Centre, online < http://www.law.go.kr/lsSc.do? menuId=0\&subMenu=3\&query $=$ 대한민국임시 $>$ (last accessed 8 April 2016). For an English translation of the Provisional Constitution of 11 April 1919, see Lee et al., supra note 21, pp. 435-6.

33. Sŏ (2012), p. 114.

34. Lee et al., supra note 21, p. 431.

35. While the Provisional Constitution of 11 September 1919 established a presidential system (taet'ongnyŏngje), parliamentary institutions were adopted after Rhee Syngman was formally impeached in March 1925, due to the diplomatic activities in which he unilaterally engaged on behalf of the provisional government in the US. See Kim (2000), p. 359. 
(2) We propose to have a government modeled after that of America, as far as possible, consistent with the education of the masses. For the next decade it may be necessary to have more centralized power in the government; but as education of the people improves, and as they have more experience in the art of self-governing, they will be allowed to participate more universally in the governmental affairs. ${ }^{36}$

As a result, education was listed not as a right, but as a duty, along with taxation and military conscription, in Article 6 of the April 1919 Provisional Constitution and Article 10 of its September 1919 counterpart, detailing the institutional structure of the new republic in exile. Education had ceased to be categorized as an obligation by the time the Provisional Charter of April 1944 was adopted - a text that is considered as bridging the constitutional experiments of the pre- and post-liberation periods. ${ }^{37}$ In addition, it should be noted that the "we" that featured in the 1919 Declaration of Independence as well as Aims and Aspirations of the New Korean Republic primarily referred to the signatories of both documents, namely enlightened elites taking on themselves to act not only on behalf, but also in place, of the people. Thirty years later, by contrast, the 1948 founding Constitution of the ROK overtly spoke in the name of "We, the people," straightforwardly borrowing the opening of the American Constitution simply in appearance, as the very choice of the word "people" (kungmin or inmin) was at stake. ${ }^{38}$

Yet, not only did the radical opposition that came to be associated with these two terms not exist during the colonial era, but it slowly emerged after 1945. As will be seen in the next section, there were proponents of recognizing the people (inmin) rather than nationals (kungmin) as the proper bearers of rights and depositories of sovereignty until the South Korean Constitution was adopted - a position exemplified by Yu Chin-o's (1906-87) draft that provided the basis for the text promulgated on 17 July 1948. In the immediate wake of liberation and before being annexed by the North, inmin was even largely part of the language through which Koreans from diverse horizons were envisioning their shared political future.

\subsubsection{Kungmin and Inmin's Post-1945 Mobilization and Recasting}

In the days that followed the 15 August 1945 capitulation of Japan in the Pacific War and termination of its colonial rule on Korea, inmin imposed itself as a favoured term to capture the people whose sovereignty had just been recovered-although it was only a matter of weeks before they would be deprived of it again as the US and the Soviet Union agreed to split the peninsula alongside the 38th parallel and to jointly occupy its territory. In the meantime, the appeal to inmin as the subject endowed with political agency to design Korea's future most visibly featured in the grassroots people's committees (inmin wiwŏnhoe) that spontaneously mushroomed throughout the country, "both at the center and in the regions," "in the brief space between liberation and the arrival of foreign occupation authorities." ${ }^{39}$ Despite the heterogeneity of these local organizations and beyond their

36. Provisional Government of the Republic of Korea (1919a).

37. Sin (2008).

38. Another fragment of the preamble illustrates the selective appropriation made of the US Constitution by its South Korean counterpart, the former's triptych "life, liberty, and the pursuit of happiness" having been replaced by "security, liberty, and happiness" in the latter.

39. Armstrong (2003), p. 48. 
function to maintain order, the people's committees generally pursued two common goals - the purge of colonial authorities and pro-Japanese collaborators on the one hand, land redistribution on the other hand - which echoed the demands of a vast majority of the Korean population at the time.

With the US-Soviet joint occupation in place by September 1945, the fate of the people's committees and their reforms greatly differed in the North and in the South. While they were recognized and reorganized by the Soviets (to ensure that Communists would dominate them, which was not necessarily the case as some, particularly in Pyongyang, had a strong Christian leadership for instance), the people's committees were banned and dissolved by Americans before the end of the year. ${ }^{40}$ The United States Army Military Government in Korea (USAMGIK)'s policy of denying the legitimacy of any pre-existing political authority also applied to the provisional government in exile, sidelined in favour of the Korean Democratic Party (han'guk minjudang), which "hastily organized the week after the American arrival, consisted of socially prominent landlords and businessmen who considered with alarm the emergence of a political organization with the socialist-sounding name of people's committees." 41

In both halves of the peninsula, selective actors (rightists south of the 38th parallel, leftists, and more specifically Communists north of it) thus gained privileged access to power thanks to occupation authorities. The mirroring dynamics behind this eradication of certain groups and promotion of others illustrate how, although the partition of the peninsula was forced upon it by foreign superpowers, domestic forces were also ready to mobilize themselves around the politics of each side. In other words, the dissensus artificially formalized by the division pre-dated it. What splitting the peninsula amounted to was turning the ideological polarization right/left, internal to Korean politics after liberation, into a spatial polarization south/north, imposed from outside. ${ }^{42}$

According to Seungsook Moon, the American occupation authorities' "prioritiz[ation of] the suppression and eradication of indigenous leftist movements and organizations, while sponsoring rightist movements and organizations ... resulted in the reproduction of the authoritarian idea and citizenship practices in South Korea." 43 This very continuity was encapsulated in the resort to kungmin - the term preferred not only by the right, but also by the centre to circumscribe the post-colonial body politic. ${ }^{44}$ To do so, one of the fora in which these forces gathered was the South Korean Interim Legislative Assembly (namchosorn kwado ippŏp ŭiwŏn), created in December 1946. On 6 August 1947, the assembly made public its Interim Constitution of Korea (chosŏn imsi yakhŏn), after having discussed at length whether its title should include or not a reference to all of Korea-the solution eventually retained—or its southern half only.

40. Ibid., pp. 48-9.

41. Robinson (2007), p. 108.

42. This historiographical view of the division emerged in the early 1980s following the publication of Bruce Cumings's first volume on The Origins of the Korean War (Cumings, 1981). It has been described by Henry Em as "critical-interactive," contrasting with the approaches that solely focus on domestic factors or international variables (such as the "orthodox-international" narrative of South Korea's official historiography blaming the Korean partition and war on Soviet ambitions, supported by the "puppet" government of North Korea; or the "liberal-international" framework seeing the USSR and the US as equally responsible). See Em (1993), pp. 453-6.

43. Moon, supra note 22, p. 20.

44. Sŏ, supra note 33, p. 114. 
This text, however, "never went into effect because USAMGIK withheld its approval," informing the interim legislative assembly on 20 November 1947 that its members having been "appointed by the occupation authorities (and the other half chosen through indirect elections)," this body "could not be seen as representing the Korean people properly." ${ }^{45}$ In its place, the US military government supported the formation of the Constituent National Assembly (chehŏn kukhoe), which was elected on 10 May 1948 and whose work was based on a constitutional draft written earlier that year by Yu Chin-o. The fact that no female candidate obtained a seat in the assembly was only one of the many flaws that plagued its coming into being. ${ }^{46}$ Held in the south only, the elections through which the constituent body was formed were denounced as endorsing the division of Korea by many political leaders, including $\mathrm{Kim} \mathrm{Ku}$ on the right of the political spectrum.

Boycotted by those who opposed it, the Constituent National Assembly was largely free to adopt a text conform to the liking of "the right-wing coalition that formed [its] hegemonic bloc" and at the head of which Rhee Syngman could be found. ${ }^{47}$ Article 2 of the Constitution promulgated on 17 July 1948 enshrined the sovereignty of the people as kungmin while its preamble spoke in the voice of "We, the people of Korea (taehan kungmin), with a glorious tradition and history from time immemorial, following the indomitable spirit of independence." Yet, the use of the term kungmin appears to have been debated up to the very end as reported by Chaihark Hahm and Sung Ho Kim:

[D]uring the drafting of the Constitution in 1948, there was a sustained debate among members of the CNA over the choice of kukmin [kungmin]. Many thought that the word should be replaced with inmin, which they believed conveyed more accurately the sense of "people" underlying the doctrine of popular sovereignty. The argument was that kukmin gave the impression of a person whose interests are always aligned with the state's, whereas the goal of providing for individual rights was to ensure that the individual was not oppressed by state power. The original draft constitution prepared by Yu Chin-o, which served as the basis for the Constitution Drafting Committee's work, in fact, had employed inmin. The committee changed it to kukmin before submitting the draft to the plenary session for deliberation. ... Ultimately, the experience of dealing with the Soviets and North Korea, which blocked the May 10 general election in the northern half of the peninsula under their control, would weigh in heavily in favor of kukmin. The term inmin—pronounced jinmin in Japanese — was the word favored by communists. One conservative member of the National Assembly made a rather emotional appeal in favor of using kukmin by stating that he was sick and tired of hearing about the loathsome "people's committees" set up in the north. What had a rather vague leftist connotation in Japan had become associated for Koreans with a hostile communist regime to the north. As a result, the drafting committee's choice of kukmin over inmin was retained. ${ }^{48}$

In Japan, where the new post-war Constitution was enacted on 3 May 1947, the choice to render the opening expression "We, the people of Japan" as nippon kokumin signalled both a continuity and a rupture with the imperial past: continuity given the fact that "kokumin had been used widely during the Meiji period to integrate the people under the emperor"; but rupture insofar as the boundaries of the nation-state now circumscribed the space within

45. Hahm \& Kim, supra note 7, p. 256.

46. Moon, supra note 22, p. 21.

47. Hahm \& Kim, supra note 7, p. 108. In the wake of liberation from colonial rule, Rhee Syngman, lacking a local base of support after having spent most of his political life abroad (mainly in the US), allied with the Korean Democratic Party, an organization in need of the nationalist credentials earned by Rhee as a result of his independence activism.

48. Hahm \& Kim (2010), p. 843. 
which sovereignty, redefined as popular, would be exercised. ${ }^{49}$ The choice to name- and to speak in the name of - the people as kokumin imposed itself against the alternative jinmin during the process of translating the constitutional draft prepared by the American occupation authorities. Because:

... jinmin had a socialist or communist flavor and conveyed a sense of the people resisting authority, whereas kokumin had a less adversarial connotation of a people harmoniously merged with the state ... all references to the 'people' were ultimately translated as kokumin. ${ }^{50}$

As the case of Japan illustrates, the ideological antagonism that had come to colour the distinction between kungmin and inmin by the time the South and North Korean Constitutions were promulgated in 1948 extended beyond their particular conflict over representation and sovereignty. Moreover, this antagonism did not entail that no commonalities underlay the conceptions of peoplehood captured by both categories. If similarities have been diachronically traced in the different versions of peoplehood articulated by enlightenment nationalists, colonial authorities, the US military government, and South Korean authoritarian regimes (as being all "collectivist and largely elitist versions" of citizenship with a "capitalistic and authoritarian undercurrent"), ${ }^{51}$ convergences between kungmin and inmin may also be synchronically identified in the 1948 Constitutions of the ROK and DPRK.

As argued by Seungsook Moon, "while the Constitution of South Korea has contained the modern rhetoric of the sovereignty of the people, in practice the de-politicization of citizenship makes political sovereignty the sole preserve of rulers and elites." ${ }^{.52}$ A corresponding logic can be found at work in the process of inmin's mobilization in the Constitution of North Korea. The ideological dimension attached to the term's deployment in this text was the result of an appropriation by Communist authorities that did not hold a monopoly over inmin in 1945. Let us recall that, even in the North, people's committees were not all spontaneously dominated by leftists, as local political configurations greatly varied from one region to another, with the strengthening of Communists' control under the Soviet impulse having been especially resisted in Pyongyang, where Christian leader Cho Man-sik (1883-1950) was most influential.

Still, the conception of peoplehood that came to impose itself after such control was secured had little to do with orthodox Marxism. Despite its emphasis on workers as being the vanguard of the revolution, the notion of inmin articulated by Kim Il-sung (Kim Il-sŏng, 1912-94), who quickly rose to prominence in post-1945 North Korean politics with the members of his Manchurian faction, was never reducible to a class definition of peoplehood as underlined by Charles Armstrong. ${ }^{53}$ The goal of building a large, populist base of support for the new regime indeed appeared at the heart of the reforms it undertook between 1946 and 1947, such as decolonization and land reform, to create a social order in which formerly marginalized groups (workers and peasants, but also women and the youth) would be integrated. ${ }^{54}$ In the process of this refashioning, inmin became associated with a new reality

\footnotetext{
49. Ibid., pp. 837-8.

50. Ibid., p. 838 .

51. Moon, supra note 22, p. 27.

52. Ibid.

53. Armstrong, supra note 39, p. 220.

54. Ibid., pp. 74-5.
} 
whose contours were envisioned by the regime's elite as encompassing rather than constricted:

\begin{abstract}
Writing in the party theoretical journal Inmin, Kim Wŏnbong [1898-1958] explained shortly after the DPRK was founded that the North Korean state was a "genuine people's regime" because the central government "represents the will of the whole Korean people, and is constructing a completely unified sovereign independent state of our fatherland." This was closer to the populist-organicist notion of "the people" found in Maoism than the class analysis of Marx or Lenin. There were "people" and "nonpeople": the former where [sic] the genuine community, living within North Korea, and the latter were outside, traitors in the South and imperialists. As Kim Wŏnbong put it, the DPRK "has expelled all pro-Japanese and national traitors and is a pannational unified government established by the representatives of the patriotic people, including workers, peasants, samuwŏn, intellectuals, and petty bourgeoisie.. ${ }^{, 55}$
\end{abstract}

This inclusiveness was visible in the 1948 Constitution of North Korea, whose sovereignty clause as articulated in Article 2 rested upon an unqualified notion of peoplehood. Only "pro-Japanese elements" were openly disenfranchised: they could neither vote nor be elected according to Article 12 and their property was confiscated according to Article 5. In other words, Article 2 did not outline a list of the social categories considered as making the body politic. This practice contrasted with both the 1936 Soviet Constitution after which the 1948 North Korean text was modelled, whose Article 1 provided "the Union of Soviet Socialist Republics is a socialist state of workers and peasants," and with the so-called Socialist Constitution (sahoejuŭi hŏnpŏp) that the DPRK adopted in 1972, whose Article 7 will be discussed later in this paper.

As stressed above, the catch-all conception of peoplehood implied in the 1948 text primarily echoed a wide definition of the social forces to be included in the project of national (re)construction. In the sense that the people in the name of which the text spoke was subordinated to this goal rather than empowered on its own, the founding Constitution of North Korea paralleled its South Korean counterpart. Whether designated as inmin or kungmin, both categories referred to national subjects for the state to mobilize rather than to political subjects able to press their rights. Far from magnifying the conflict that opposed them, the following section suggests that the two Koreas' lexical divergence over naming the people may even be the sign of a consensus regarding the horizon toward which inmin and kungmin were projected: the building of two separate nation-states.

\title{
2.2 The Political Reality of National Division versus the Legal Fiction of Unity
}

The founding constitutions of North and South Koreas have in common to preserve the legal fiction of national unity, by claiming that their respective territories extended over the whole peninsula. This sovereignty dispute is usually believed to be at the root of the inter-Korean disagreement upon which the 1948 establishment of two rival states was premised. Even though each Korea-and, more specifically, each Korean leader (Kim Il-sung in the North and Rhee Syngman in the South) — then denied the legitimate existence of the other, such a conflict does not exhaust the dynamics of both states' coming into being. As manifested in the content of their constitutions, the institutional reality that each set in place contributed to acknowledging more than negating the division. In other words, the North and South Korean

55. Ibid., pp. 220-1. 
Constitutions can also be read as taking part in the process of building two separate states in which both halves of the peninsula were already engaged by the end of the year 1945. This logic was not only apparent in the 1948 texts but became even more explicit after their concurrent 1972 revisions.

\subsubsection{Contradictions in the 1948 Founding Constitutions}

As mentioned before, Articles 4 and 103 of both Koreas' founding Constitutions respectively provided that the territory of the ROK covered the entire peninsula and that the capital of the DPRK was Seoul, thus preserving the legal fiction of national unity. Yet the institutional reality set in place by both Constitutions largely contradicted these claims. In each Korea, constitution making accompanied the building of a separate nation-state more than it resisted such process. This confirmation of the division, however, did not entail its political acceptance-the latter only came in several stages $(1972,1991$, and 2000) that will be subsequently detailed.

If the North and the South concentrated on consolidating distinct systems on the portion of territory under their respective control in 1948, the objective each pursued of becoming a strong state was primarily aimed at taking over its counterpart. Increasingly present in the DPRK's propaganda of the late 1940s, the concept of "democratic base" (minju kiji) was precisely deployed to capture the idea that the next phase of the revolution, after its launch and completion in the north (deemed by authorities to have been achieved by the summer of 1949), was its extension to the rest of the peninsula. ${ }^{56}$ The plan to "unify the homeland," however, was far from being confined to North Korea:

The existence of two states on a peninsula that leaders of both sides insisted should be a single political unit presented a volatile and dangerous situation. South Korean President Syngman Rhee's frequent call for a "march north" to liberate North Korea from the communists is well known, and in 1949-the year U.S. forces were withdrawn from South Korea-the DPRK claimed some 1,863 cases of ROK military aggression across the $38^{\text {th }}$ parallel. It is conceivable that either side could have started a war; but in the event, by June 1950 the North was better prepared for war, had the backing of its patron state, and ultimately made the decision to attack its rival in the South. ${ }^{57}$

In light of this confrontation, the reality of the division was both institutionally affirmed (through the establishment by each Korea of its own political, administrative, and socioeconomic structures) and ideologically rejected (through the claim that only one legitimate Korea existed) in the founding Constitutions of the North and the South. In other words, both texts contributed to ratifying the division through the institutionalization of two separate, strong states meant to enable reunification to happen, even by force. This configuration differs from the situation of the Republic of China (or Taiwan) in the conflict of sovereignty that has opposed it to the People's Republic of China since the late 1940s. The former's efforts to maintain the legal fiction of unity have indeed been far-reaching, resulting in both the ideological and institutional negation of the division for more than four decades. Comparing these two sets of cases requires examining not only the manifestations, but also the conditions that led to the formation of their respective conflicts of sovereignty.

56. Ibid., p. 225.

57. Ibid., pp. 235-6. 
The Constitution of the Republic of China was adopted in Nanjing on 25 December 1946 and became effective on 1 January 1947, namely before Nationalists retreated to Taiwan in 1949 following their loss against Communists in the civil war (1946-50). The constitutional framework under which the Republic of China on Taiwan still operates was therefore elaborated before the national division, although the text itself was not the product of any unity. While the National Assembly in charge of writing the 1947 Constitution was supposed to gather all political forces, no delegates were sent by the Chinese Communist Party. ${ }^{58}$ This is not the only mark of conflict embedded in the history of the text, whose promulgation almost immediately coincided with its suspension. On 18 April 1948, the National Assembly adopted "the Temporary Provisions Effective During the Period of Mobilization for the Suppression of Rebellion which amended the Constitution and granted emergency powers to the President," instituting "a state of emergency [that] would last for more than forty years" until the Temporary Provisions were lifted in 1991 and the 1947 Constitution enforced again. $^{59}$

In contrast to the Republic of China having retained the Constitution inherited from before the partition, the Korean Constitutions were an outcome of the 1945 division. Despite their territorial clauses perpetuating the legal fiction of unity, the two texts' design of representative institutions encapsulated both Koreas' acceptance of the division, as opposed to its refusal by the Republic of China until the early 1990s. The fact that the ROK and DPRK legislative bodies - respectively known as the National Assembly (kukhoe) and the Supreme People's Assembly (ch'oego inmin hoeǔi)—have each operated since their founding with delegates of and for the South or the North only embodies a clear rupture with the Taiwanese framework. ${ }^{60}$ Let us recall that the assembly in charge of framing the ROK Constitution was formed following elections exclusively held in the peninsula's southern half, with no seats left to represent the northern side, which was already engaged by that time in its own constitution-making process. ${ }^{61}$

On the contrary, the representative institutions of the Republic of China were historically caught in a double dilemma: on the one hand, pretending to represent China as a whole from 1949 to 1991 (which resulted in the non-renewability of the seats held by delegates from the first, pre-partition parliament for more than four decades); on the other hand, preventing the representation of Taiwan's insular population in the absence of elections (with both the executive and the legislature having come from the continent in the wake of the Nationalists' retreat in 1949). These fictitious arrangements were confirmed and legitimized on 29 January 1954 when, "faced with the impossibility of holding elections on mainland China, the Grand Justices Council—responsible, inter alia, for interpreting the Constitution-handed down

58. Mengin (2015), p. 24.

59. Ibid., p. 26.

60. To my knowledge, only Article 8 of the supplementary rules (puch'ik) of the 1962 ROK Constitution made allusion to the issue of representing North Korea, providing that "The number of the members of the National Assembly after the recovery of the national territory (kukt'o subok) shall be separately determined by law" (Republic of Korea, 1964. All subsequent quotations of the ROK Constitution as amended in 1962 come from this source).

61. While, according to Dae-Kyu Yoon, the North Korean Constitution was drafted in April 1948, this process began in late 1947 based on Andrei Lankov's study of Korea-related decisions by the Soviet Politburo: "On November 18, the Third Session of the North Korean People's Assembly adopted an official resolution on the commencement of work on the Constitution." The draft that was made public in early February 1948 was then "sent for examination to Moscow, where the experts from the Soviet Central Committee carefully examined it." See respectively Yoon (2003), p. 1292 and Lankov (2005), pp. 396-7. 
Interpretation No. 31 that postponed sine die elections," leaving in power "all of the first-term members of both the Legislative and Control Yuans." 62

Both institutions, similarly to the now defunct National Assembly (distinct from the Legislative Yuan and endowed with the power to elect the President and Vice-President as well as to amend the Constitution), were therefore "frozen in office so as to artificially represent the whole China." ${ }^{, 3}$ Even after a series of constitutional amendments adopted from 1991 onward enabled "the establishment of a regime representing the island population alone," "a complete overhaul of the 1947 institutions was not conceivable given the opposition of the Nationalist old guard and of Beijing to any initiative likely to seal the partition of China." 64 As a result, the status of Taiwan has remained that of a "state without statehood" given its non-, and even de-, recognition in 1971, when its seat at the UN became occupied by the People's Republic. Although both Chinas employ the same terms to refer to the country (zhonghua) and its people (renmin, made of the same characters that compose inmin in Korean), the fact that they cannot coexist on the international stage invites to relativize the disagreement at stake in the Korean case.

The two Koreas are still technically in a state of war, as the conflict that opposed them between 1950 and 1953 only ended with the signing of an armistice but not the conclusion of a peace treaty. Although this unresolved state of things persists, it has not prevented the evolution of their sovereignty dispute. The fact that this dispute can be said to have abated over time does not mean that the peninsula is free of tensions, but that frictions no longer crystallize around the claim by each state that the other is illegitimate. As will be examined in the next section, the 1972 reforms of the North and South Korean Constitutions marked an important step along the way of their mutual recognition, reinforcing the logic embedded in their 1948 texts: the building of separate orders, each having different institutions to represent-at least in theory-its own people.

\subsubsection{Change and Permanence in Post-1972 Revisions}

The date of 27 December 1972 coincided with two important and simultaneous reforms of the North and South Korean Constitutions. The former was replaced by the so-called Socialist Constitution of the DPRK, while the latter was revised for the seventh time since its adoption into the Yusin (or revitalization) Constitution of the ROK. ${ }^{65}$ The two processes intervened in a double context: the authoritarian radicalization of both regimes-with the North Korean Constitution of 1972 consecrating the consolidation by Kim Il-sung of his power while its South Korean counterpart contributed to the tightening by Park Chung-hee (Pak Chŏng-hŭi, 1917-79) of his rule; and the impact of the 4 July 1972 Joint Communiqué on inter-Korean relations. $^{66}$

62. Mengin, supra note 58, p. 31. "Though at the central level the mandates had not been taken away from their holders who were still alive, from 1969 onwards, supplementary elections were held to fill the vacant seats in the assemblies, and from 1972 onwards, the elected representative[s] of Taiwan province had increased in number, their mandates becoming renewable at the end of their respective terms" (ibid., p. 79).

63. Ibid., p. 68.

64. Ibid., pp. 115, 117.

65. Earlier revisions of the constitutions had taken place in 1954 (twice), 1955, 1956, and 1962 in the DPRK, and in 1952, 1954, 1960 (twice), 1962, and 1969 in the ROK as will be evoked in the second part of this article.

66. The passage of the Yusin Constitution amounted to a second coup d'état by Park Chung-hee, in power since 1961, who declared martial law throughout the country on 17 October 1972, dissolved the National Assembly without being 
"[T]he first document to be agreed upon by both North Korea and South Korea following the division of the Korean Peninsula in 1945," the Joint Communiqué enshrined three principles for reunification: its achievement without external interference, through peaceful means, and on the basis of a great national unity transcending political and ideological antagonisms. ${ }^{67}$ In addition, the Communiqué "pushed the North-South dialogue to a new level, as both sides agreed to cease slandering one another, to begin various forms of exchanges, to setup a hotline between Seoul and Pyongyang, and to form a South-North Coordinating Committee" to mitigate tensions. ${ }^{68}$ This shift in inter-Korean relations was recorded in the constitutional changes enacted in 1972 in several ways.

First of all, the new North Korean text abandoned the reference to Seoul as the capital of the DPRK. The 149th and last article of the 1972 Socialist Constitution thus read as "The capital (sudo) of the Democratic People's Republic of Korea is Pyongyang." 69 The introduction of the language of (re)unification ( $t$ 'ŏngil) in the preamble and Article 5 further confirmed the text's acknowledgement of the division's political reality. ${ }^{70}$ As declared in Article 5, "The Democratic People's Republic of Korea strives to achieve the complete victory of socialism in the northern half, drive out foreign forces on a national scale, reunify the country peacefully on a democratic basis and attain complete national independence." In the South, the provision equating the territory of the ROK with that of the entire peninsula was left intact in the 1972 Constitution but the rhetoric of (re)unification was also inserted in the preamble as well as in Chapter 3 dedicated to a new institution, the National Conference for Unification. ${ }^{71}$

Although such a body did not survive the Park regime's end in 1979, the language of (re) unification has endured in both the South and North Korean Constitutions since its introduction in 1972. In the meantime, the two states' mutual recognition continued to progress. In September 1991, both Koreas' concurrent accession to the UN signalled the possibility of their coexistence as independent nation-states on the international stage, as did the "Agreement on Reconciliation, Non-Aggression, and Exchanges and Cooperation" or North-South Basic Agreement (nambuk kibon habŭisŏ) signed on 31 December of the same year. The two Koreas' mutual recognition was eventually sealed by the joint summit of the summer 2000 held in Pyongyang between their respective leaders Kim Jong-il (Kim Chŏng-il, 1941/1942-2011) and Kim Dae-jung (Kim Tae-jung, 1924-2009), followed by the one that gathered Kim Jong-il and Roh Moo-hyun (No Mu-hyŏn, 1946-2009) in 2007.

Yet the constitutional reforms of 1972 should not be seen as having set into motion a linear process that came to a conclusion in 2000 . The congruence displayed by the replacement of the North Korean text and the amendment of its South Korean counterpart when it comes to

(F'note continued)

legally empowered to do so, and set up the Emergency State Council (pisang kungmu hoeŭi) that amended the Constitution, concentrating more power than ever in the president elected by and chairman of the National Conference for Unification (t'ongil chuch'e kungminhoeŭi). See Constitutional Court of Korea (2008), p. 82.

67. Shin (2012), p. 1.

68. Ibid.

69. DPRK (1972). All subsequent quotations from the 1972 Socialist Constitution of the DPRK come from this source.

70. Like the Chinese language, the Korean language only knows the term "unification" to designate what in English is usually translated as "reunification."

71. ROK (1973). All subsequent quotations from the Constitution of the ROK as amended in 1972 come from this source. 
timing - 27 December 1972 — and content—in terms of (re)unification discourse-also masked the deepening of divergences related to the formalization of a socialist regime in the North and establishment of the Yusin system in the South. In the address that Park Chung-hee gave before the adoption of the Yusin Constitution, renovating institutions was clearly tied to the necessity of building national strength:

We have always attempted awkwardly to imitate closely the democratic institutions of others. We can no longer sit idle while wasting our precious national power in imitating the systems of others. ... It is my conviction that the revised draft of the Constitution promulgated today aims at peaceful unification and guarantees maximum efficiency in mobilizing national strength and consolidating the foundation of stability and prosperity, thus setting the norm for a proper constitutional order which will enable the democratic system to develop in a manner most properly adapted to our national realities and ideals. ${ }^{72}$

The language employed in the North was no less confrontational as illustrated by the speech that Kim Il-sung delivered while presenting the new Constitution to the Supreme People's Assembly on 25 December 1972, two days before its adoption by a unanimous vote:

With the institution of the Socialist Constitution, the Government of the Republic will have a new weapon of the proletariat dictatorship and our people will be provided with a dependable legal guarantee in the struggle to achieve the complete victory of socialism and the independent, peaceful reunification of the country. The coming into force of the Socialist Constitution in the northern half of the Republic will greatly encourage the people in south Korea who are fighting for the democratization of society and the country's independent, peaceful reunification. ${ }^{73}$

Providing in its Article 1 that “The Democratic People's Republic of Korea is an independent socialist state representing the interests of all the Korean people (chosŏn inmin)," the country's new Constitution further proclaimed in its Article 11 that "The State defends the socialist system against the subversive activities of hostile elements at home and abroad and revolutionizes and working-classizes (nodong kyegŭphwa) the whole society by intensifying the ideological revolution." As will be explored in the second part of this paper, Article 11 and others signalled a profound remoulding of the contours of peoplehood and the correlated boundaries of enmity compared with the 1948 document. In addition, various institutional arrangements of the founding Constitution were altered with the creation, for instance, of the presidency to which Kim Il-sung was elected on 28 December 1972 (the day following the adoption of the new Constitution) after having occupied the function of premier since 1948.

In contrast to the North Korean regime's decision to dispose of its original constitutional framework, continuity has prevailed in the South where the founding Constitution is still in force. Despite the text's numerous amendments, the legal fiction of national unity has not fully disappeared due to the preservation of its 1948 territorial clause. As of today, the division's denial remains inscribed in Article 3 of the Constitution equating the territory of the ROK with the entire peninsula. This fiction produces legal effects in at least two realms: national security and citizenship. The constitutional negation of North Korea's sovereignty is indeed responsible for its designation as an "anti-state organization" (pan'gukka t'anche) in the National Security Act (kukka poanpŏp), also adopted in 1948 and still in force. In spite of various revisions, the law continues to define the anti-state organizations whose activities it

72. Park (1972), p. 28.

73. $\operatorname{Kim}(1972 b)$, pp. 35-6. 
suppresses as the groups that "claim the title of government" (i.e. North Korea) or that "aim at disrupting the state." ${ }^{, 74}$ Under the National Security Act, communicating with members of anti-state groups (which include, by definition, all North Koreans) is forbidden without governmental authorization.

The constitutional negation of the North's statehood yields an additional, and possibly antinomic, consequence. North Korean nationality not being recognized by the ROK, the North is construed as a territory that hosts residents who are de jure citizens of the South. In the frame of the ROK's legal system, North Koreans therefore appear as figures of the other and the same, members of the imagined national community with whom interacting is nonetheless prohibited. Upon arriving in the South, North Koreans are seldom treated as fellow nationals. They are first and foremost considered as escapees or refugees, and therefore subjected to special security screening (to prove that they are neither spies nor ethnic Koreans from China) as well as adaptation programmes. To be eligible for treatment as full citizens of the South, North Koreans have to prove that they hold North Korean nationality according to North Korean laws. In other words, possessing a non-existing citizenship paradoxically represents the legal requirement to be stripped of it. ${ }^{75}$

Yet these effects of the South's constitutional denial of the North's sovereignty are more marginal than central in the overall framework set in place by fundamental norms. In both halves of the peninsula, constitution making has been primarily part of the process of building two states as institutionally, if not ideologically, recorded in their 1948 founding documents. The legal fiction of national unity was then enshrined in the territorial clause of each text but did not affect the design or functioning of the different branches of government, representative of the South or the North only. With the constitutional reforms of 1972 that introduced the language of "peaceful (re)unification" in the new Socialist Constitution of the DPRK and the Yusin Constitution of the ROK, the fiction of national unity appears to have receded even further.

By explicitly acknowledging the division's political reality for the first time, these two texts consolidated its institutionalization, already engaged in 1948. In light of this convergence, the supposed inter-Korean dispute over peoplehood materialized by the use of inmin in the North and kungmin in the South does not hold. Rather than translating a disagreement over rival visions of the same community, the deployment of inmin and kungmin in the ROK and DPRK Constitutions captures certain commonalities in the way both Koreas envisioned their members as "dutiful nationals subject to continuous mobilization and control" for the purpose of building strong but separate nation-states. ${ }^{76}$ Maybe

74. The original Korean version of the National Security Act and its subsequent revisions are accessible online at < http://www.law.go.kr/lsSc.do?menuId=0\&p1=\&subMenu=1\&nwYn=1\&section=\&tabNo=\&query=국가보안법> (last accessed 9 April 2016), while an unofficial English translation of the law can be consulted online at < http://www. hartford-hwp.com/archives/55a/205.html > (last accessed 9 April 2016).

75. Guichard (2016), pp. 97-100. As pointed out by Chulwoo Lee, being a citizen of the DPRK according to North Korean law does not suffice to guarantee being recognized as a national of the ROK. Indeed, "because of gaps between the nationality laws of South and North Korea, some members of the North Korean citizenry are excluded from the citizenship of the Republic of Korea" (Lee, 2015, p. 23). The challenges to which these gaps confront public authorities precisely shed light on "the shaky and hazy administrative practices of admission and exclusion" that make up an important but overlooked dimension of the politics of citizenship and national membership according to Lee (ibid., p. 31).

76. Moon (2005), p. 21. 
more surprisingly, defining and ascribing such membership have been a matter of protracted conflictuality within each Korea, as the rest of this article examines.

\section{WHOM “THE PEOPLE” IS: TWO INTRA-KOREAN DISAGREEMENTS}

Inmin and kungmin should be seen in the light of not only their synchronic commonalities in the North and South Korean Constitutions, but also their diachronic transformations throughout the successive versions of each text. Indeed, constituting these two categories has alternatively entailed incorporating or countering competing claims about peoplehood articulated within the North and the South by different political actors and/or at different political moments. In 1948, the contours of the body politic as envisioned in the ROK and DPRK Constitutions reflected the domestic imperative of building a large base of support by which both new regimes were confronted. In this respect, the identity and rights of inmin and kungmin outlined in the founding texts, particularly in the economic realm, appeared highly similar and syncretic - two characteristics that faded in the course of revising both documents. Rather than abating over time, the intra-Korean dispute about peoplehood has thus survived and even amplified, leading post-1948 constitutional reforms to reshape in major and often narrow ways the boundaries of who is included in or excluded from the community of national subjects.

\subsection{Disagreeing over Peoplehood in the North}

The North Korean Constitution of 1948 was not only revised, but also replaced, in 1972 by a document called the Socialist Constitution of the DPRK, which has since been amended in 1992, 1998, 2009, 2010, 2012, and reportedly in 2016. ${ }^{77}$ Aside important institutional transformations that will not be the main focus of the analysis, a fundamental rupture between the 1948 and 1972 texts concerns the evolution of inmin from a nationalist to a class construct. While the inclusiveness of peoplehood has thus subsided from one Constitution to the other, its collectivist dimension has been correlatively strengthened, as illustrated by the reinforcement of references to the family as a metaphor of society.

\subsubsection{Enumerating Who Belongs}

As evoked before, the conception of inmin that emerged with the North Korean regime was premised on nationalism rather than Marxism, with the founding Constitution of 1948 departing from the Soviet Constitution of 1936 on which it was, selectively, modelled by its adoption of an inclusive-rather than class-based-definition of peoplehood:

Indeed, the 1948 DPRK constitution did draw heavily from the 1936 Stalin constitution, but a close reading of the two shows that the former was not merely a slavish copy of the latter. In particular, the first section on "Basic Principles" (which has no equivalent in the Soviet text) gives a very different nuance to the North Korean document, incorporating a broad-based, populist rhetoric rather than Soviet-style references to class struggle. Unlike the USSR, the DPRK does not refer to itself as a "state of workers and peasants" but says instead that "authority is in the people" (inmin). ${ }^{78}$

77. NK News (2016).

78. Armstrong, supra note 39, p. 201. 
According to Charles Armstrong, this rhetoric particularly translated the political vision embraced by Kim Il-sung and the partisans who had waged anti-Japanese guerrilla warfare along his side in Manchuria, a group that had come to dominate the North Korean system by 1948. These veterans' belief in the intertwined necessity to make the nascent party-state "broad-based socially but highly disciplined politically" first derived from the strategy their formative experience as guerrilla fighters had taught them to adopt: developing "a tightly knit core bound by personal connections to the leader and a social inclusiveness that depended particularly on the support of the poorest segment of peasant society." priority identified by Kim and his companions for the construction of a new regime was not to initiate a class struggle, but to terminate the one against colonialism, by eliminating "all the remnants of Japanese imperialist rule from the political and economic life of Korea" as set by Article 1 of the 1946 Twenty-Point Platform. ${ }^{80}$

This objective did not only imply nationalizing the assets of the former colonial government-extensive given the integration of the northern part of the Korean peninsula in the industrial complex that had sustained Japan's war economy-but also the property of those who had collaborated with it, such as landowning elites. ${ }^{81}$ In this respect, several articles of the founding Constitution were particularly notable. Article 5, section 2 provided that "Mines and other mineral wealth, forests, waters, major enterprises, banks, [...] transport, communication, water-works, natural energy, as well as all the property which formerly belonged to the Japanese government, the Japanese nationals or pro-Japanese elements, are owned by the state" while Article 6, section 1 stated that "The land owned by the Japanese government and the Japanese nationals as well as the Korean landlords is confiscated." These, alongside Article 6, section 2 abolishing the tenancy system, should be read as clauses confirming rather than announcing post-liberation policies, with the laws on agrarian reform and nationalization dating back to 5 March and 10 August 1946, respectively.

Still, it is important to stress that neither private property per se nor all property owners were targeted under the Constitution. The former was recognized in Article 5, section 1, according to which "the ownership of the means of production takes the following forms: state ownership; cooperative ownership; ownership by private natural or by private juridical person." On the one hand, private ownership of land was not abolished, but limited to "those who till land with their own labour" by Article 6, section 3. On the other hand, the protection of private property also extended to the ownership of "medium and small industrial enterprises, medium and small trade, raw materials and manufactured goods, residences and outhouses, articles of domestic economy, income and savings" according to Article 8, section 1 . Its sections 2 and 3 additionally safeguarded the right to inherit private property as well as encouraged "creative initiative in private economy."

As contended by Kim Il-sung in his above-mentioned 25 December 1972 speech preceding the adoption of the Socialist Constitution, pursuing decolonization had theoretically justified the inclusion rather than exclusion of the local bourgeoisie after liberation. As long

79. Ibid., p. 242.

80. An English translation of the Twenty-Point Platform is reproduced in Fukushima (1975), pp. 302-3.

81. "After the division, 80 percent of heavy industry, 76 percent of mining, and 92 percent of electricity-generating capacity lay in the North, while light manufacturing and agriculture dominated in the South" (Robinson, supra note 41, p. 120). 
as they were not collaborators but opponents of colonialism, "national capitalists" were thus presented as allies rather than enemies of the North Korean revolution:

The national capitalists in colonial, semi-feudal society, though inconsistent, have some revolutionary spirit and are keenly interested in the anti-imperialist, anti-feudal, democratic revolution. In the light of such characteristics in these capitalists, we drew them over to the side of the revolution and, together with them, carried out the national-liberation struggle and the democratic revolution. From the beginning, our policy in regard to the national capitalists was not only to carry out the anti-imperialist, anti-feudal, democratic revolution together with them, but also to take them along with us to a socialist, communist society. Therefore, we could not expropriate the entrepreneurs and traders in the stage of socialist revolution just because the capitalist traders and manufacturers were the targets of the revolution. Moreover, we had no need to expropriate them because capitalist trade and manufacturing were totally destroyed in the war and the entrepreneurs and traders supported the Party's line of socialist revolution. ${ }^{82}$

In Kim's account, the experience of the Korean War and of the massive destructions suffered by the country's economy in its course not only made necessary, but also facilitated the North's full transition to socialism. ${ }^{83}$ Just like the Constitution of 1948 largely came after the measures it called for had been implemented, the Socialist Constitution of 1972 endorsed rather than heralded the transformation of the North Korean system, particularly recorded in its Chapter 2, dedicated to the economy. In contrast to the 1948 recognition of the possibility of privately owning the means of production, such ownership was only entrusted to the state and co-operative organizations by Article 18 of the 1972 text. The only form of private property now protected under Article 22 corresponded to "the working people's personal property (kaein soyu)," either "derived from socialist distribution according to work done and from additional benefits granted by the State and society" or consisting of "the products from the inhabitants' supplementary husbandry including those from the small plots of cooperative farmers."

This transformation was politically accompanied by a redefinition of peoplehood in the 1972 Constitution, no longer as encompassing as it had been in its 1948 counterpart. While the founding text only disenfranchised "pro-Japanese elements," the contours of the body politic drawn in the 1972 document were openly more restrictive as stated in Article 11, according to which "The State ... working-classizes the whole of society by intensifying the ideological struggle." The sovereignty clause no longer recognized inmin as the source and depository of power but, following Article 7, attributed-and limited-it to the "workers (nodongja), peasants (nongmin), soldiers (pyŏngsa) and working intellectuals (kŭllo int'eri)." In addition, Article 2 provided that "The Democratic People's Republic of Korea rests on the politico-ideological unity of the entire people based on the worker-peasant alliance led by the working class, on the socialist relations of production and the foundation of an independent economy."

This language is reminiscent of the 1936 Soviet Constitution that provided the model for the 1948 North Korean text, albeit not on this very point. The 1972 enumeration of

82. Kim, supra note 73 , p. 11.

83. On the one hand, the impoverishment of peasants as a result of the war was deemed to justify the implementation of a "cooperative form of agriculture" in the countryside while, on the other, the losses suffered by "capitalist traders and manufacturers" in towns were said to have led them to embrace "the road to socialism" (ibid., pp. 6-7). 
peoplehood, however, should not be interpreted as an affirmation of doctrinal orthodoxy on the part of Kim Il-sung and the group of Manchurian veterans who not only dominated the political system in 1948 but had also eliminated all potential rivals since. ${ }^{84}$ On the contrary, the Socialist Constitution was the one to introduce the "Juche (chuch'e) idea" as a guiding principle of the DPRK. Usually translated as self-reliance, chuch'e was defined as "a creative application of Marxism-Leninism to the conditions of our country" in Article 4, before any reference to Marxism-Leninism was altogether abandoned from the North Korean Constitution when it was revised in 1992 (Article 3 then contented itself to define chuch'e as "a world outlook centered on the people [saram], a revolutionary ideology for achieving the independence of the masses of people [inmin]"). ${ }^{85}$

The enumeration of peoplehood introduced in 1972 was retained throughout later constitutional reforms, which amended without replacing the Socialist Constitution. However, slight variations can be identified from one text to another, the people being composed of the “workers (nodongja), peasants (nongmin), working intellectuals (kŭllo int'eri), and all working people (modŭn kŭllo inmin)" but not soldiers per Article 4 of the 1992 and 1998 documents. ${ }^{86}$ The latter were eventually reinserted (as kuin instead of pyŏngsa) in Article 4 of the 2009 text, kept as such in 2012. The year 2009 was when the so-called military-first (sŏn'gun) doctrine found its way in the Constitution as a guiding principle, featuring alongside chuch'e in Article 3: "The DPRK is guided in its activities by the Juche idea and the Songun idea, a world outlook centered on the people, a revolutionary ideology for achieving the independence of the masses of people." 87

Interestingly, the ellipsis of soldiers from 1992 to 2009 did not point to a marginalization of the military, neither as a social group nor as a principle of social organization, as exemplified by the continued centrality of the duty of national defence. Article 28 of the 1948 founding Constitution provided "It is the duty of every citizen of the DPRK to defend the homeland (choguk)" in section 1 and "To defend the homeland is the highest duty (ch'oedaeŭimu) and honour (ch'oedae yŏngye) of every citizen of the DPRK” in section 2. While Article 72, section 1 of the 1972 text continued to define national defence in the same terms, the language of the South Korean Constitution has similarly evoked since 1948 the armed forces' "sacred duty (sinsŏnghan ŭimu) of protecting the national territory (kukt'o)" and all citizens' duty to defend it as prescribed by Articles 6 and 30 of the original text. The North and the South's convergence over conceiving inmin and kungmin as duty-bound and loyal subjects should not however mask the maximalist demands of allegiance that came to permeate the Constitution of the DPRK, as captured by the multiplication of its references to familialism and collectivism over the years.

84. "By the 1960s, the former Manchurian partisans were at the apex of the power system in the DPRK, and those who had been aligned with the Southern Workers' Party, the Soviets, and the Chinese in Yan'an had almost all been purged, executed, sent into exile, or otherwise eliminated from positions of power" (Armstrong, supra note 39, p. 241). The Manchurian group's total consolidation of power can be seen as alluded to in the 1972 text by the newly inserted Article 61 consecrating the special status of revolutionary fighters and their families: "Revolutionary fighters, the families of revolutionary and patriotic martyrs, the families of the People's Armymen, and disabled soldiers enjoy the special protection of the State and society."

85. DPRK (1993). All subsequent quotations from the Socialist Constitution of the DPRK as amended in 1992 come from this source.

86. DPRK (1993) and DPRK (1998).

87. DPRK (2009). 


\subsubsection{The Strengthening of Familial and Collectivist Claims}

In parallel with the above-mentioned changes identified in the North Korean state's discourse on peoplehood (changes which amounted to the continuation of its post-1945 trajectory rather than to a rupture), an additional transformation rested in the increasing use of the family metaphor to represent not only the people's unity, but also the regime's expectation of its loyalty. Although present in post-liberation narratives from the outset, the resort to this metaphor has tended to reinforce itself over time. As emphasized in Kim Il-sung's 25 December 1972 speech, "Today our society has been turned into a great harmonious Red family where the entire people are closely united as a political force." 88 Although the family image was not mentioned in the founding Constitution of 1948, it featured prominently in the preamble of 1972 dedicated to celebrating Kim's achievements:

Regarding "The people are my God" as his maxim, Comrade Kim Il Sung always mixed with the people, devoted his whole life for them and turned the whole of society into a large family (taekajŏng) which is united in one mind by taking care of the people and leading them through his noble benevolent politics.

As pointed out by Charles Armstrong, this rhetoric was far from being idiosyncratic to North Korea, although it acquired centrality in the regime's propaganda due to its longevity and dynastic mode of succession, Kim Il-sung having been replaced by his son Kim Jong-il at his death in 1994, and Kim Jong-il by his own son Kim Jong-un (Kim Chŏng-ŭn, 1983/1984-) after his passing in 2011. ${ }^{89}$ It has been debated whether these metaphors signalled or not a continuity with traditional Confucian ethics, which invites the analysis to consider how, and to which extent, gender roles were redefined in the Constitutions of 1948 and 1972. Article 22, section 1 of North Korea's founding Constitution provided that "Women are accorded equal rights with men in all spheres of government, political, economic, social, cultural activity"- a claim that was not merely declarative given the passage on 30 July 1946 of a law on equality of the sexes that granted women the right to free marriage (Article 4), the right to free divorce (Article 5), as well as the right of succession to property, including land, on an equal footing with men (Article 8). ${ }^{90}$ Yet:

[I]f gender equality was a radical introduction, North Korea's approach to the family was quite conservative. This "profamily" orientation was a consistent element of the North Korean system. The North Korean regime from the beginning was never critical of the family as such, and unlike China, for example, North Korea never engaged in experiments with breaking up the family unit. On the contrary, the political system of the DPRK would build on the structures and metaphors of the nuclear family throughout its existence. ${ }^{91}$

88. Kim, supra note 73, p. 28.

89. "In the use of family metaphors and symbols, North Korean nationalism has been typical of postcolonial nations, if more literal than most. For a postcolonial people, as Homi Bhabha remarks, 'The nation fills the void left in the uprooting of communities and kin, and turns that loss into the language of metaphor.' These metaphors of 'community and kin' were central to the North Korean representation of the nation. As in all effective nationalisms, North Korea extended outward the concept of agnatic kinship, routinizing family metaphors until they no longer seemed metaphorical and took on a concrete literalness. Over time these symbols would evolve into the 'fatherly leader,' the 'mother party,' and the son as the legitimate heir to the Great Leader" (Armstrong, supra note 39, p. 222).

90. In addition, the law contained such provisions as the prohibition of polygamy and prostitution (Article 7). An English translation of the law is reproduced in Fukushima, supra note 80, pp. 312-13.

91. Armstrong, supra note 39, p. 94. The importance of the family is also visible in the South Korean Constitution, which provided until 1980 that, if "marriage shall be based on the equality of men and women," the state should give special protection to "the purity (sun'gyŏl) of marriage and the health of the family." This provision, enshrined in the 
While the Constitution of 1948 protected marriage and the family (Article 23, section 1), this clause was completed by the provision that "The State pays great attention to consolidating the family (kajŏng), the cell of society (sahoeŭi sep'o)" in Article 63, section 2 of the 1972 text. ${ }^{92}$ In accordance with this novel concern, collectivism (chiptanjuŭi), a term absent from the 1948 Constitution, was introduced as a principle in two new provisions all contained in Chapter 4 dedicated to the fundamental rights and duties of citizens (kongmin). Article 49, placed at the beginning of Chapter 4 in the 1972 document, thus proclaimed that "In the Democratic People's Republic of Korea the rights and duties of citizens are based on the collectivist principle of 'One for all and all for one' (hananŭn chŏnch'erŭl wihayŏ, chŏnch'enŭn hanarŭl wihayŏ)" while Article 68, section 1 intimated that "Citizens must display a high degree of collectivist spirit."

It has been argued by Kim Sŏng-bo that the difference between inmin, the people, and kongmin, citizens, is not one of unit (between a collective and the individuals who compose it) but instead one of substance (between an abstract political concept and a concrete legal category). ${ }^{93}$ While the two terms as deployed in the DPRK's founding Constitution can be seen as displaying this kind of nuance, entrusting sovereign power to the people but specific rights and duties to citizens, a close reading of its 1972 counterpart suggests an additional mode of articulation between both constructs. The narrowing of peoplehood's contours observed in the Socialist Constitution indeed coincided with citizenship's relegation to being not only a residual, but also a subordinated status. ${ }^{94}$

Since 1972, this asymmetrical relationship has been most forcefully embodied in the role attributed to North Korean law, defined by Article 17 as an instrument at the service of a class conception of inmin that all kongmin must obey: "The law of the Democratic People's Republic of Korea reflects the will and interests of the workers, peasants and other working people, and it is consciously observed by all State organs, enterprises, social cooperative organizations and citizens. $" 95$ In other words, the people was made to enjoy not only political, but also legal, ascendancy over the citizenry through this provision, consecrating an unprecedented gap between the privileges attached to the attribution of sovereign power to a socially selective definition of inmin (restricted to "workers, peasants, soldiers and working intellectuals" per Article 7) and the obligations incurred by the possession of nationality by all kongmin.

While the dissociation between peoplehood and citizenship introduced in the 1972 Socialist Constitution clearly departed from the inclusive claims of the 1948 founding text, the growing use of familial metaphors and collectivist rhetoric from one document to the other was arguably intended to overcome, or overshadow, such a dichotomy. The familial

(F'note continued)

ROK 1948 Constitution as Article 20, was amended in 1980 into "Marriage and family life shall be entered into and sustained on the basis of individual dignity and equality of sexes" per Article 34, also stating "The State shall endeavor to protect motherhood" (ROK, 1981. All subsequent quotations of the ROK Constitution as amended in 1980 come from this source). Both clauses are currently part of Article 36.

92. In 1992, the expression "cell of society" was replaced by "basic unit of social life (sahoeŭi kich'ung saenghwal tanwi)."

93. Kim (2009), p. 87.

94. A related argument has been advanced by Xingzhong Yu in his analysis of the differentiation between peoplehood and citizenship in the successive constitutions adopted by the People's Republic of China in 1954, 1975, 1978, and 1982: “All four PRC constitutions as well as the Common Program used the concepts of both 'people' and 'citizen,' with the former referring to the good elements of society and the latter, both the good and bad elements" (Yu, 2002, p. 294).

95. Article 17 became Article 18 after the Constitution was amended in 1992. 
incarnation associated with the figure of Kim Il-sung in the preamble of 1972 was extended in the preamble of 2012 to the figure of Kim Jong-il, whose achievements it posthumously consecrated. Leaving the language of the 1972 Constitution unchanged, the 2012 document celebrated how "Comrade Kim Il Sung and Comrade Kim Jong Il always mixed with the people, devoted their whole lives to them and turned the whole of society into a large family which is united in one mind." 96 Yet, this very unity has presupposed the internalization by kongmin of the "socialist norms of life and the socialist rules of conduct" deemed inherent to inmin since the 1970s. ${ }^{97}$

The requirements to be or become a citizen of the DPRK are not prescribed by the Constitution, but by a nationality law, first adopted on 9 October $1963 .^{98}$ The founding document of 1948 did not comprise any reference to nationality apart from oblique ones, as expressed in Article 26 recognizing "the right of asylum to foreign nationals persecuted for fighting for democratic principles or national liberation movement, or for the interests of the working people or for freedom of scientific and cultural activities" as well as in Article 31 guaranteeing to "national minorities (sosu minjok) who have the citizenship of the DPRK ... equal rights with the Korean citizens" alongside with "freedom to use their mother tongues (mogugŏ) and develop their own national culture (minjok munhwa)."99

Whereas the latter provision no longer appeared in the Socialist Constitution of 1972, the former was preserved, with slight alterations, as Article 66 now safeguarding "the right of asylum to foreign citizens persecuted for fighting for peace and democracy, national independence and socialism, or for the freedom of scientific and cultural pursuits." A new clause was also inserted in Article 65 to protect Korean nationals residing abroad, namely outside the peninsula: "All Korean citizens in foreign lands [haeoe, literally overseas] are legally protected by the Democratic People's Republic of Korea." Such a provision primarily addressed the status of Koreans in Japan (known as chaeil kyop'o in Korean or zainichi in Japanese), incentivized to opt for the nationality of the ROK after the normalization of its diplomatic relations with Japan in $1965 .{ }^{100}$

96. Translation based on an update of the 2009 version only mentioning Kim Il-sung. While Kim Il-sung was elevated to the title of eternal chairman of the Republic (konghwagukŭi yŏngwŏnhan chusŏk) in 1998 (the first revision of the Constitution following his death in 1994), Kim Jong-il was correspondingly made eternal chairman of the National Defence Commission (yŏngwŏnhan kukpangwiwŏnhoe wiwŏnjang) in the 2012 version of the text (the first revision after his passing in 2011). In its preamble, Kim Jong-il was notably praised for having "turned our fatherland into an invincible state of political ideology, a nuclear-armed state (haek poyukuk) and an indomitable military power, paving the ground for the construction of a strong and prosperous nation" (translation provided in Yonhap (2012)). This reference to North Korea as a nuclear state was a novelty introduced by the Socialist Constitution of the DPRK as amended in 2012. Since the death of Kim Jong-il, a second amendment to the Constitution was reportedly conducted in 2016 to replace the National Defence Commission (kukpangwiwŏnhoe) with the State Affairs Commission (kungmuwiwŏnhoe) as the highest executive organ, of which Kim Jong-un is the chairman. See NK News, supra note 77.

97. Per Article 67 of the 1972 Constitution, "Citizens must strictly observe the laws of the State and socialist norms of life and the socialist rules of conduct."

98. An English translation of the law is reproduced in Kim (1972a), pp. 324-5.

99. Although this provision is believed by various analysts to have been literally borrowed, despite its lack of relevance, from the 1936 Constitution of the Soviet Union, a multinational state, Kim Sŏng-bo has called attention to the absence of an expression such as "national" or "ethnic minorities" from the Soviet text. One possible explanation for the inclusion of this provision in the North Korean Constitution resided in the DPRK's professed intention to protect the Chinese minority present on its soil (hwagyo) in the hope that the vast ethnic Korean population mostly living in Northeast China (known as chosŏnjok in Korean or chaoxianzu in Chinese) would be similarly treated. See Kim, supra note 92 , p. $90-1$.

100. Indeed, "as part of the conditions for normalization of relations with South Korea, Japan agreed in 1965 to render rights to reside permanently in Japan to those Koreans who claim allegiance to the Republic of Korea" (Kim, supra note 97, p. 328). 
While the majority of the over two million Koreans residing in Japan after the war decided to repatriate to the Korean peninsula, those who stayed in the archipelago numbered approximately 600,000, constituting Japan's largest minority. Discouraged by post-war political and economic conditions to return to the southern provinces from which it overwhelmingly came, this diaspora was soon considered by Japanese authorities as "stateless":

In 1947, the Diet passed the Alien Registration Law that identified Koreans as belonging to chōsen based on their family registers and required Koreans to carry alien registration cards at all times. However, because the Republic of Korea (ROK) and the Democratic People's Republic of Korea (DPRK) did not come into existence until 1948, Koreans in Japan during this time were held to be stateless. Consequently, chōsen referred not to a nationality but to an ethnic group. ${ }^{101}$

Even after the term became associated with the DPRK, many first-generation Koreans in Japan continued to identify with chōsen (denoting both pre-partition Korea and North Korea) rather than kankoku (South Korea only) on their alien registration certificates. This default or voluntary allegiance with the northern regime, however, made their status fragile vis-à-vis both the Japanese state, particularly after its 1965 recognition of South Korean nationality, and the North Korean one, as the protection it offered in the 1972 Constitution's Article 65 for instance was purely nominal. ${ }^{102}$ The same precariousness certainly plagues the fundamental rights granted to the DPRK's citizens not only abroad, but also at home, to whom the successive versions of the Constitution have guaranteed a variety of freedoms (including freedom of speech, the press, assembly, association, and demonstration) known for being systematically denied by the state. The conceptualization of constitutions as documents that offer claims about both the people, namely the framed, and the framers is useful to make sense of the pretension lying behind the pretence of fundamental rights' provisions in this case: pretension to legitimately represent and democratically govern the people on which the language of political modernity is based, even for authoritarian regimes.

It should also be noted that the North and South Korean Constitutions not only contribute to constructing whom the people is, but also what its "true" representation (taep'yo) commands. Both founding documents interestingly defined representation as implying the direct accountability and therefore removability of public officials as prescribed by Article 4 of the DPRK text in case electors' confidence was betrayed and by Article 27 of its ROK counterpart in case officials committed unlawful acts. ${ }^{103}$ Although the North Korean clause, after having been suppressed in 1972, was reinserted in 1992 with minimal rewording and has since remained in the Constitution, its South Korean equivalent was extensively rewritten in 1962 to revoke citizens' right to petition for the removal of public officials and

101. Chung (2009), p. 155.

102. The fact that "no office at any governmental level in North Korea possesses documentation or registration of any sort on Koreans in Japan, while no Korean living in Japan, regardless of political sympathy, exercises voting rights or any other form of civil and political participation in North Korean society" has led Sonia Ryang to contend that "the self-referential nomenclature of the North Korea-supporting expatriates, konghwaguk haewoe kongmin (DPRK's overseas nationals), is not based on a legal foundation but is an ideological enunciation" (Ryang, 2009, p. 9). Today, the 5,000 or so Koreans in the archipelago who do not possess ROK nationality are still held stateless by Japanese authorities.

103. According to Article 4 of the 1948 DPRK Constitution, "Deputies to all the organs of state power are responsible to their electors for their activities. The electors may recall their deputies before the expiration of the term in office in case the deputies betray their confidence." Similarly, per Article 27 of the 1948 ROK Constitution, "Public officials shall be the trustees of the sovereign people and shall at all times be responsible to the people. All citizens shall have the right to petition for the removal of public officials who acted unlawfully." 
has since been left unchanged. ${ }^{104}$ In addition, the model articulated in the North Korean Constitution since 1972 clearly equates the representation of the people with the reflection (panyŏng) of their will (ŭisa) and interests (riik), illustrating how claims to be representative also involve claims about representation whose supposed transparency is no less constructed than the idea of peoplehood itself.

\subsection{Disagreeing over Peoplehood in the South}

Far from being the antithesis of its North Korean counterpart, the 1948 founding Constitution of the ROK presented many similarities with the text of the DPRK when it comes to defining the rights and duties of the people, particularly in the economic realm. Yet the claims made by the South Korean document should not be seen as solely disputing the North's legitimacy. They were also addressed to a domestic audience that had much reason to doubt the new regime's intention to represent its interests. Despite nine amendments, five of which corresponded to regime transitions, the 1948 Constitution remains in place today, raising the issue of the extent to which its discourse on peoplehood has changed over time, especially since the transition to democracy that South Korea experienced in 1987.

\subsubsection{Domestic Legitimacy and Compromise}

One of the most commented aspects in comparisons drawn between the North and South Korean founding Constitutions arises from the convergence of their economic systems. While private ownership of the means of production was protected by the DPRK's fundamental norms in 1948 as seen before, the text enacted by the ROK that same year institutionalized a social rather than liberal market economy. ${ }^{105}$ This congruence did not simply originate in the competition in which both Koreas found themselves at their creation, but it also proceeded from the domestic imperatives that each faced. Whereas the northern regime engaged early on in an effort to build a large base of support, which measures such as land redistribution and the purge of the former colonial administration helped it to secure, the southern regime was in search for a social compromise that could compensate for its intrinsic deficit of legitimacy. This shortfall stemmed from the post-liberation order's absence of clean rupture, and even continuity, with the Japanese era-a reality compromising the claim that the establishment of the ROK carried on "the spirit of independence" embodied in the 1 March 1919 anti-colonial struggle as proclaimed in the preamble of its founding Constitution.

While popular reforms were implemented in the northern part of the peninsula under Soviet control, they were hindered or delayed in its southern half, where the military government of the US relied, administratively, on the structures as well as personnel of the colonial state apparatus and allied, politically, with conservative groups notably composed of

104. According to Article 7 of the 2012 version of the DPRK Constitution, "Deputies to all the organs of State power at all levels have close ties with their constituents and are accountable to them for their work. The electors may recall the deputies they have elected if the latter are not to be trusted" (translation based on DPRK, 2009). Per Article 7 of the ROK Constitution as last amended in 1987, "All public officials shall be servants of the entire people and shall be responsible for the people. The status and political impartiality of public officials shall be guaranteed as prescribed by Act" (ROK, 1988. All subsequent quotations of the ROK Constitution as amended in 1987 come from this source). Since 1962, citizens can seek redress against an act unlawfully committed by a public official but can no longer petition for his or her removal.

105. Park (2011), p. 270. 
landlords and businessmen suspected of collaboration. The South Korean Constitution of 1948 did not content itself to negate this legacy of both Japanese and American occupations by appealing to that of the independence movement. As analyzed by Chaihark Hahm and Sung Ho Kim, its economic provisions also amounted to an attempt by framers to make claims of representation beyond their own elitist and exclusionary interests:

From the beginning, arguably, the right-wing coalition that formed a hegemonic bloc within the National Assembly suffered from a legitimacy deficit. The fact that domestic left-wing factions had recently been purged from the South Korean political scene called into question its representativeness. The legitimacy problem was due in large part to the perception that the right-wing coalition-especially those belonging to the Korean Democratic Party, which represented the landowning class interests - had prevailed in the general election, despite suspicions of collaboration under colonial rule, thanks to USAMGIK patronage. More importantly, the communist regime emerging north of the $38^{\text {th }}$ parallel was already carrying out extensive socioeconomic reforms under Soviet supervision, whereas such reform, albeit urgently called for, was not making much progress in the south. In order to compensate for their contested "regime legitimacy," thus, the drafters of the Constitution opted for a socioeconomic regime more progressive than would have been warranted by their narrow class interests or political inclinations. Seen in this light, the Economy Chapter and related articles were a means by which to win the hearts of the general populace in the south and to counteract communist infiltration from the north. ${ }^{106}$

The challenge of winning people's hearts must be seen in light of ordinary Koreans' enthusiasm for socialism after 1945. ${ }^{107}$ Although most of "the leftist groups capable of challenging the regime were driven underground" before the ROK's founding three years later, contestation was still strong and even turned into rebellion in 1948 in regions such as South Chŏlla and Cheju Island. ${ }^{108}$ Between 4 September 1948 and 30 April 1949, 89,000 arrests were reportedly conducted by the government of Rhee Syngman while the National Security Act "was rushed through the Assembly" on 1 December 1948 to crack down on so-called anti-state activities. ${ }^{109}$ Against this contentious background, the social promises made by the Constitution adopted that same year can be said to have aimed at terminating disagreement, at least at the discursive level, since state violence was responsible, in practice, for physically silencing dissent.

In this perspective, Article 84 not only inscribed social justice as the principle of the new economic order, but also a "balanced national economy (kyunhyŏng innŭn kungmin kyŏngje)" as its horizon, granting the state both the ownership of natural resources (Article 85) and the control of public utilities (Article 87, section 1). In addition, Article 86 provided that land had to be redistributed to the peasants and Article 88 that private enterprises could be nationalized when necessary for the nation's security (kukpangsang) and livelihood (saenghwalsang). Yet, both Articles 85 and 88 were to be read in light of the requirement that "expropriation, use, or restriction of private property for public purposes

106. Hahm \& Kim, supra note 7, p. 108.

107. “Given contemporary South Korea's staunch anti-Communism, it is hard to imagine socialism's popularity in the 1940s Korea. But in the period after the Liberation, socialists drew tremendous support from the landless, intellectuals, and factory workers" (Robinson, supra note 41, pp. 102-3).

108. Lee (2002), p. 45.

109. Henderson (1991), pp. 149-50. By the spring of 1950, the new law had been used to imprison some 58,000 individuals. Since its inception, the security legislation has therefore embodied more than the reality of the national division. Its genealogy highlights how the division itself has given birth to a more insidious line of separation than the $38^{\text {th }}$ parallel, a division not only between both Koreas, but also inside each. 
shall be accompanied by due compensation" under Article 15. This provision thus guaranteed the right to private property and against its confiscation while nonetheless subjecting the exercise of such a right to public welfare (konggong pongni). Lastly, Article 18 safeguarded not only the "freedom to association, collective bargaining, and collective action" of workers, but also their right to "share in the profits" of private enterprises.

Neither constitutional discourse nor state violence, however, could effectively counterbalance the lack of legitimacy from which the South Korean state was suffering. While the land reform eventually launched in June 1949 succeeded in securing South Korean farmers' support for the new regime, ${ }^{110}$ the frailty of its base was only fully remedied with the advent of the Korean War, in a double way: externally, vis-à-vis the North's regime, and internally, vis-à-vis the South's society. As pointed out by Jang-Jip Choi, "whereas before the war, the South Korean state had a weak local base of support, the war gave the state an ideological basis for building its legitimacy": anticommunism, "articulated and experienced in everyday life." 111 In the wake of the war, the conditioning by the US of its much-needed financial assistance to the rewriting of the 1948 Constitution's Chapter 6 on the economy motivated the amendment which was passed on 29 November 1954.

While Article 84 (identifying social justice as the principle of the ROK's economic order) and Article 86 (related to land redistribution) were preserved, substantial changes were introduced in the rest of the chapter to reduce the purview of the South Korean state's role. ${ }^{12}$ In this respect, state ownership of natural resources previously provided in Article 85 of the founding Constitution was withdrawn from this clause while the government's management of public utilities was removed from Article 87. As for Article 88, it was rewritten as prohibiting the transfer of private enterprises to state or public ownership, "except in cases specifically designated by law to meet urgent necessities of national life." Article 18 on workers' rights was maintained as such until they lost the right to share in the profits of private enterprises in 1962 - a forfeiture that was followed by the right to collective action being seriously altered in $1972 .^{113}$

In the context of South Korea's state-led development launched from the 1960s onward, the language of realizing a just and balanced economic order still professed in the successive versions of South Korea's founding Constitution thus became inseparable from the justification of labour control. In contrast to the constitutional reform of 1954 aimed at aligning the ROK with free-market principles, the 1962 and 1972 amendments also partially reaffirmed the government's capacity to intervene in the economy, including its power to "impose restrictions or obligations" for the use of land (Articles 114 and 119 of the revised constitutions of 1962 and 1972) or to promote the development of agricultural co-operatives (Articles 115 of 1962 and 120 of 1972, in which these co-operatives were renamed "farming and fishing villages"). In this perspective, the 1980 Constitution even allowed "monopolistic

110. Park, supra note 104, p. 277.

111. Choi (1993), p. 22.

112. ROK (1955). All subsequent quotations from the ROK Constitution as amended in 1954 come from this source.

113. Per Article 29, section 3 of the ROK Constitution as amended in 1972, "The right to collective action of public officials and workers engaged in State, local autonomous governments, state-run enterprises, public utilities or enterprises which have a serious impact on the national economy may be either restricted or denied in accordance with the provisions of law." Workers' rights as enumerated in Article 18 since the founding Constitution were first moved to Article 29 when the text was amended in 1962. 
and oligopolistic practices" to be "properly regulated and coordinated" in Article 120, section 3 .

The rewriting of economic provisions illustrates how the post-1948 constitutional history of South Korea is irreducible to the revision of executive powers clauses through which it is commonly narrated. Indeed, although the 29 November 1954 reform was initiated by the administration of Rhee Syngman to expunge from Chapter 6 the arrangements deemed incompatible with capitalism under the pressure of the US, this amendment is more infamously remembered for having removed the two-term limit imposed on the presidential office. ${ }^{114}$ Article 55 according to which "re-election to consecutive terms [for the office of President and Vice-President] shall be permissible for one time only" was not modified on that occasion but the supplementary rules added in 1954 stated that "The proviso of Paragraph 1 of Article 55 of this Constitution shall not apply to the incumbent of the office of President at the time of promulgation of this Constitution." This exemption allowed the founder of the ROK's First Republic to successfully run for a third term in 1956 and to try to assume a fourth in 1960 .

Yet the blatantly rigged election of April 1960 ignited nation-wide protests, principally fuelled by students, whose magnitude led Rhee to flee to Hawaii before the end of that month. The political transition that ensued was consecrated by the constitutional amendment of 15 June 1960, which brought about a short-lived democratic government and parliamentary system under Premier Chang Myon (Chang Myŏn, 1899-1966), the Second Republic (1960-61). ${ }^{115}$ Interestingly, the preamble to the Constitution was kept the same despite the changes instituted by the new regime, leaving unmentioned the students' uprising out of which it was born. As we shall see, this episode was only appropriated in later revisions of the text, alongside an expression that the Constitution of the Second Republic borrowed from the 1949 Basic Law for the Republic of Germany on which it was selectively modelled: the "basic order of free democracy" (chayu minjujŭi kibon chilsŏ), a syntagm copied on its German counterpart (freiheitlich demokratische Grundordnung).

This reference was introduced in Article 13 to authorize the dissolution (haesan) of political parties whose purposes or activities were contrary to the basic order of free democracy - a dissolution to be requested by the president of the ROK and pronounced by the newly created Constitutional Court of Korea (hŏnpŏp chaepanso) following the example of Article 21, section 2 of the German basic law. ${ }^{116}$ As a similar provision was retained throughout all amendments of the South Korean Constitution after 1960, its text has remained committed to defending itself against another figure of enmity than the enemy of the state, who threatens national security. The Constitution also appears ready to confront the enemy of the democratic constitutional order, namely political parties unwilling to abide

114. An earlier reform of the Constitution had taken place in the midst of the Korean War on 7 July 1952, with the National Assembly convening in Pusan instead of Seoul under North Korean control, to turn the presidential election from indirect into direct suffrage (ROK, 1952).

115. Another revision of the Constitution was passed on 29 November 1960 to lift the prohibition against retroactive punishment and enable the passage of ex post facto legislation against the former regime's supporters.

116. Per Article 21, section 2, "Parties that, by reason of their aims or the behavior of their adherents, seek to undermine or abolish the free democratic basic order or to endanger the existence of the Federal Republic of Germany shall be unconstitutional. The Federal Constitutional Court shall rule on the question of unconstitutionality," Basic Law for the Federal Republic of Germany, 2012, English translation accessible on the website of the Bundestag, online < https://www. bundestag.de/blob/284870/ce0d03414872b427e57fccb703634dcd/basic_law-data.pdf > (last accessed 8 April 2016). 
by its rules. ${ }^{117}$ Yet, the act and language of defending the constitutional order may not only help to protect democracy against political threats, but can also contribute to fashioning a certain kind of order from which some actors will be excluded: Nazis and Communists in post-war West Germany ${ }^{118}$; the forces behind the popular democratization movement (particularly students and workers) in post-1987 South Korea-forces whose disidentification with the people in the name of which the Constitution speaks will be evoked in this article's last section. ${ }^{119}$

The expression "basic order of free democracy" was enshrined in the preamble of the ROK Constitution-where it still features - in 1972, when the third constitutional revision adopted under Park Chung-hee was enacted. The 1972 preamble's narrative was particularly telling of both continuities and ruptures in South Korea's post-1945 construction of peoplehood:

We, the people of Korea, possessing a glorious tradition and history from time immemorial, imbued with the sublime spirit of independence as manifested in the March $1^{\text {st }}$ Movement, and with the ideals of the April $19^{\text {th }}$ Righteous Uprising and the May $16^{\text {th }}$ Revolution, now being engaged in the establishment of a new democratic Republic which consolidates further the basic, free democratic order on the foundation of the historic mission of the peaceful unification of the fatherland .... Do hereby amend, through national referendum, the Constitution.

The reference to the independence movement of 1 March 1919 and the claim of anti-colonial legitimacy that accompanies it have been two constants in the ROK Constitution since 1948, similarly to its founding's rooting in the peninsula's illustrious past. The mention of Korea's "glorious tradition(s) (pinnanŭn chŏnt'ŏng)" was also inserted in the Socialist Constitution of the DPRK but in relation to recent history (that of the "revolutionary struggle against the imperialist aggressors") rather than ancient (labelled "immemorial" according to the South Korean text). ${ }^{120}$ Indeed, the North Korean document of 1972 primarily insisted on the necessity to break away from former times as expressed in Article 37 on combatting the "tendency to return to the past" and Article 38 calling for "eliminat[ing] the way of life left over from the old society."

In the South, including or excluding political episodes other than the 1 March 1919 independence movement has corresponded with shifting uses of history to (re)found the constitutional order. The mention of the "May $16^{\text {th }}$ Revolution (5. 16 hyŏngmyŏng)," referring to the military coup d'état through which Park Chung-hee seized power in 1961, was understandably limited to the revisions of the Constitution undertaken under his rule in 1962, 1969, and 1972. In these three texts, however, such an allusion was always supported

117. The institution to which the authority of dissolving political parties is entrusted has varied since 1960, from the Supreme Court (taebŏbwŏn) per Article 7 of the 1962 and 1969 documents to the Constitutional Committee (honpŏp wiwŏnhoe) following Article 7 of their 1972 and 1980 counterparts. The existence of a Constitutional Court was only reintroduced in 1987.

118. Two cases of dissolution were rendered in the early years of the Federal Constitutional Court: in 1952, against the Socialist Reich Party, openly neo-Nazi; and in 1956, against the Communist Party of Germany.

119. Although the Constitutional Court of Korea has only pronounced one case of dissolution, against the Unified Progressive Party (t'onghap chinbodang) in 2014, its jurisprudence for instance upheld the validity of the National Security Act by recasting the law as an instrument to protect the "basic order of free democracy" in 1990. For a detailed analysis of the court's decision, see Guichard, supra note 75, pp. 73-7.

120. Following Article 3 of the North Korean 1972 Constitution, "The Democratic People's Republic of Korea is a revolutionary State power which has inherited the brilliant traditions (pinnanŭn chŏnt’ŏng) formed during the glorious revolutionary struggle against the imperialist aggressors and for the liberation of the homeland and for the freedom and well-being of the people." 
by the reference to the "April $19^{\text {th }}$ Righteous Uprising (4. 19 ŭigŏ)" of 1960 that ousted Rhee Syngman and led to the democratic interval that Park's coup interrupted. As mentioned above, the preamble to the revised Constitution of the Second Republic, enacted in 1960 following the collapse of Rhee's regime, referred to the independence movement of 1 March 1919 but not to the students' uprising out of which it was born. This episode did not feature either in the preamble of the Constitution as revised in 1980 but was reinserted in the text of 1987, whose emphases should be read in light of its silences.

\subsubsection{Transitioning to Democracy}

"People (kungmin) are the masters of the country, and the people's will must come before everything else." ${ }^{121}$ On 29 June 1987, this dramatic acknowledgement was pronounced in a nationally televised address by an unlikely voice for political reform: General Roh Tae-woo (No T'ae-u, 1932-). His speech was all the more surprising since the incumbent regime had been brought to power by a 1979 military coup d'état led by Chun Doo-hwan (Chŏn Tu-hwan, 1931-) in which Roh himself participated. As unexpected as Roh Tae-woo's declaration was, it did not come out of nowhere, but was prompted by the mass street protests ignited throughout South Korea on 10 June, following his designation as the ruling Democratic Justice Party (minju chŏngŭidang)'s candidate for the coming presidential race. This nomination amounted to a succession choice by Chun Doo-hwan, as the 1980 Constitution-whose reform the opposition parties had been calling for since 1985-provided for the indirect election of the president every seven years, leaving the vote in the hands of a compliant electoral college.

Popular mobilization against the Chun regime did not start in 1987, but the struggle for change considerably amplified in June of that year. During these few weeks, contestation sustained since the 1970s by anti-authoritarian forces (mostly composed of students, workers, and church activists) was joined by the urban middle class, outraged by widely publicized cases of torture against young militants. ${ }^{122}$ It is believed that a combination of factors, from the very scale of the June demonstrations to the prospect of the 1988 Olympic Games scheduled in Seoul, prevented the ruling elite from resorting to martial law and violence the way it had in 1980, resulting in the death of hundreds protesters in the city of Kwangju. ${ }^{123}$ As repression did not appear a viable response to the mass rallies, now supported and attended by the middle class, Roh's 29 June speech heralded a series of eight major concessions, starting with the promise to amend the Constitution and to modify the electoral law in order to allow the direct election of the president.

The impact of these promises was immediate, as the parliamentary opposition, gathering the factions of Kim Young-sam (Kim Yŏng-sam, 1927-2015) and Kim Dae-jung in the newly formed Reunification Democratic Party ( $t$ 'ongil minjudang), instantly seized the opportunity for change opened by the announced reforms, concentrating its efforts on negotiating the revision of the Constitution. The Eight-Member Political Talks (8in chŏngch'i hoedam) were the negotiation format that the leaders of the Democratic Justice

121. New York Times (1987).

122. Robinson, supra note 41 , p. 167.

123. Immediately after the incident, "estimates of casualties varied from the government's figure of 191 killed (including 23 soldiers), to claims by dissidents that 2,000 or more perished" (West, 1997, p. 93). 
Party and the Reunification Democratic Party-Roh Tae-woo on the one hand, Kim Youngsam on the other-resolved to adopt. The talks proceeded daily from 3 to 31 August, when a final agreement on the text of the revised Constitution was reached. ${ }^{124}$ The main point on which negotiations focused revolved around the presidency - a function that Roh Tae-woo, Kim Young-sam, and Kim Dae-jung all came to occupy after $1987 .{ }^{125}$

Such an outcome was made possible by the one-term limit to the presidential office imposed in Articles 70 and 128 of the revised Constitution, but it was not predetermined by this institutional constraint. ${ }^{126}$ Indeed, the 1980 Constitution of the Fifth Republic already provided for a "one-time, seven-year term, with no possibility for constitutional amendment to extend one's term or seek a second term" - a measure that "was an important redeeming grace for the new military leadership, which lacked legitimacy" according to Dae-Kyu Yoon. ${ }^{127}$ In 1987, the presidential term was reduced to five years and the non-re-election clause retained not only to avoid the constitutional abuses characteristic of previous regimes, but also out of a compromise between the three candidates of the coming presidential race, none of whom was sure to win. ${ }^{128}$

Although the amendment of 1987 was the first of South Korea's constitutional reforms to take place following discussions between the government and the opposition, its process was controlled by political elites whose interests were far from being absolutely antagonistic. Rival parties were instead united around a consensual and common objective: resisting the pressure for systemic and substantive reform exerted by the popular democratization movement, composed of the various grassroots groups (mainly student organizations, trade unions, and church activists) which had been mobilized against authoritarianism since the 1970s and prompted the Chun regime's collapse. In this perspective, Jang-Jip Choi has demonstrated how the modalities of the 1987 transition, and of its constitution-making moment in particular, made it possible to exclude the "movement forces" who had brought about the demise of authoritarian rule:

The period from June 29, 1987, until the constitutional amendments were adopted in the National Assembly in October of the same year can be called the period of pact-making between the ruling and the democratic forces in Korea. The bilateral negotiations took the form of a political meeting between representatives of the ruling and opposition parties, participating on behalf of major political forces of the time. But these roundtables meetings for negotiating democratic institutions were a political game among the elites of institutional politics, and did not involve movement forces. ${ }^{129}$

While redesigning the presidential election (from indirect to direct suffrage) and term (from seven to five years, non-renewable) had been the main focus of discussions between the ruling and opposition parties, additional elements of compromise appeared in the amended

124. On the Eight-Member Political Talks, see Cho (2004), pp. 182-97.

125. Roh Tae-woo was elected in December 1987 with $36.6 \%$ of the vote (against $28 \%$ to Kim Young-sam and 27\% to Kim Dae-jung); Kim Young-sam in December 1992 with $42 \%$ of the vote (against $33.8 \%$ to Kim Dae-jung); and Kim Dae-jung in December 1997 with $40.3 \%$ of the vote (against $38.7 \%$ to the conservative candidate Lee Hoi-chang (Yi Hoe-ch'ang, 1935-)).

126. Article 70 of the Constitution states that the president, elected for five years, shall not be re-elected while Article 128, section 2 guarantees that Article 70 cannot be revised and the presidential term prolonged to benefit the incumbent.

127. Yoon (2010), p. 19.

128. Ibid., p. 27.

129. Choi (2012), p. 100. 
Constitution of 1987. Defining the role of the army was, for instance, one of the most divisive issues. While the opposition "wanted the preamble to proscribe the military's involvement in politics and the body [of the Constitution] to forbid 'any kind of military intervention for any reason'," it had to settle for less. ${ }^{130}$ By contrast, the ruling camp obtained that fundamental norms continue to entrust the armed forces with "the sacred mission of national security and the defense of the land" in exchange for the mention in Article 5, section 2 that "their political neutrality shall be maintained."

Claims emanating from political parties, however, were not the only ones that composed the text and subtext of the 1987 Constitution. Conspicuously absent from its making and narrative was the voice of the groups engaged in the fight for democracy since the 1970s. By tracing "the mission of democratic reform and peaceful unification of our homeland" to the anti-colonial struggle of 1 March 1919 and the student revolution of 19 April 1960 that put an end to the dictatorship of Rhee Syngman, the Constitution's new preamble voluntarily omitted any reference to the later pro-democracy movement and what its members considered a foundational event: 18 May 1980, or the Kwangju uprising. During the constitutional negotiations of August 1987, the ruling party of Chun Doo-hwan and Roh Tae-woo, who both held prime responsibility for this event's repression, had agreed with the opposition camp that "neither the Fifth Republic nor the Kwangju struggles would be cited, and [that] the preamble would convey the people's right to resist by invoking the April 1960 revolution." 131

This substitution amounted to obliterating the distinctive significance of Kwangju, deriving from the fact that its occurrence represented the turning point after which a counter-hegemonic understanding of the people's history and identity developed among democratization activists. According to Henry Em:

[I]t was the people's uprising in the city of Kwangju in $1980 \ldots$ and the massacre perpetrated by South Korean troops that finally broke the South Korean government's ideological hegemony. The magnitude of the state violence drove students and intellectuals to search for the structural and historical origins of South Korea's dictatorships. ... Students and intellectuals sought to constitute the minjung (the subaltern) as a national and nationalist subject, a subjectivity that could be an alternative to and autonomous from nationalist narratives authorized by either the North Korean or the South Korean state. ${ }^{132}$

Challenging South Korea's pervasive anti-Communist ideology prompted students and intellectuals to embrace a new national imaginary—one in which minjung (also translated as the masses or common people) replaced kungmin as the "true" incarnation of peoplehood. As pointed out by Namhee Lee, "the dichotomy of the world as abang (friends) and t'abang (enemies) became crucial" in the minjung discourse, which defined as its adversaries the forces held responsible for maintaining the Korean people in an oppressed and divided state, namely the authoritarian regime, the business conglomerates (chaebŏl), and foreign powers (particularly the US). ${ }^{133}$ As the very leaders behind the perpetration of the Kwangju massacre negotiated the 1987 change of regime and the correlated reform of the Constitution,

\footnotetext{
130. Cho, supra note 123 , p. 186.

131. Ibid.

132. Em, supra note 24, p. 16.

133. Lee (2007b), pp. 135-6.
} 
its preamble's pledge "to consolidate national unity with justice, humanitarianism and brotherly love, and to destroy all social vices and injustice" while silencing the memory of 18 May 1980 could only resonate as bitter irony to the forces of the democratization movement.

On 29 October 1987, the revised text was submitted for ratification to citizens in a national referendum that proved a plebiscite in favour of the amended Constitution, with a turnout of $78.2 \%$ and an approval rate of $93.1 \% .{ }^{134}$ These figures pointed to the satisfaction of an overwhelming majority of the South Korean voting-age population-including the "relatively conservative urban middle class that had tipped the balance in favor of the popular reform"-with the nature and extent of the democratization process, relegating to the background students' and workers' demands for 'the freedom to organize labor, the institution of distributive justice, the elimination of the National Security Law, and the creation of a social welfare system." 135 After the change of regime, minjung groups thus continued to advocate their maximalist vision of democracy in the name of being the "true" incarnation of the people, whose voice the elite-controlled transition to democracy had excluded.

In so claiming, the minjung movement contested the construction of peoplehood embodied in kungmin by inverting rather than overcoming its "strategy of dichotomization" between members and non-members of the body politic. ${ }^{136}$ Yet, under the laws of South Korea, membership in the community of national subjects never fully overlapped with nationality itself. In other words, qualifying as a citizen of the ROK does not appear incompatible with being legally categorized and treated as an anti-national element, namely as an enemy. If the latter is always constituted as the "other," he is not necessarily an "alien." The foregoing case of North Koreans-who are granted the status of citizens according to the ROK nationality rules but are considered as members of an "anti-state organization" following the definition of the DPRK provided by the National Security Act-epitomizes this ambivalence without being its only instantiation.

South Koreans themselves can be, and minjung groups during the 1990s certainly were, designated and sanctioned as threats to "the security of the state as well as the existence and liberty of kungmin" that the National Security Act's Article 1 purports to protect. As pointed out by Jung-Eun Lee, the post-authoritarian repression of minjung protests however tended to rest on the "categorical" rather than "situational" threats posed by the distinct "social-demographic identities" of the movement's activists and their perception by authorities as "the most formidable challengers to the status quo." ${ }^{\prime 137}$ The National Security Act's enforcement patterns in the decade following the regime change further confirm that the law's most widely used provision-Article 7 punishing by up to seven years of imprisonment forms of expression such as "praising (ch'anyang)," "encouraging (komu)," or "sympathizing with (tongjo)" "an anti-state organization, its members, or any person under its direction"-primarily served

134. Kihl (1988), p. 7.

135. Robinson, supra note 41 , p. 167.

136. Lee (2007a), pp. 295-6. For a similar argument, see also Moon, supra note 22, p. 27. Although South Korean civil society had undergone a "great paradigmatic shift from people (minjung) to citizen (simin)" by the end of the 1990s (Lee, 2011, p. 42), simin organizations have also been criticized for not fully breaking away from the construction of peoplehood embodied in kungmin: "While the citizens' organizations have contributed to the democratization of authoritarian citizenship conveyed for long by the term kungmin, ironically their practices have perpetuated the idea of grassroots citizens as objects of mobilization, rather than autonomous actors and decision makers" (Moon, supra note 22 , p. 25).

137. Lee (2013), p. 478. 
to criminalize a wide range of speech acts associated with the anti-capitalist, anti-imperialist, and pro-reunification demands of the minjung discourse. ${ }^{138}$

As a result, the silencing of these alternative claims has not been confined to the 1987 process and outcome of revising the ROK Constitution among political elites. Policing what counts or not as permissible speech in South Korean democracy has also importantly relied on the continued deployment of the National Security Act. Far from being a vestige of the authoritarian era, the resilience of this law is thus better understood as having contributed to enforce the non-inclusive legacy of the transition: that of democracy's institutionalization on behalf of the people as kungmin but against the voice of the people as minjung.

\section{CONCLUSION}

The constitutions of North and South Koreas have spoken in the name of the people since their promulgation in 1948. Both texts, however, resort to distinct terms to designate the people whose sovereignty they enshrine: inmin in the North and kungmin in the South. While such lexical divergence is largely interpreted as manifesting and magnifying the two Koreas' founding dispute over representing the people, this article has argued that the extent of their disagreement deserves to be relativized. Despite the ideological antagonism that today shapes the uses of inmin and kungmin, both categories are irreducible to it. Historically, the two terms coexisted as illustrated by their deployment in the discourse of enlightened elites at the turn of the twentieth century and by their circulation in the constitutional experiments of the provisional government in exile during the colonial era. After the 1945 liberation and de facto division of the Korean peninsula, their antinomy only emerged progressively as each construct became annexed by the forces-rightists in the South and Communists in the North-whose rise to power the joint US-Soviet occupation facilitated. Politically, this polarization did not prevent the ROK and the DPRK from articulating close conceptions of peoplehood in their founding documents, inmin and kungmin being envisioned as objects of mobilization rather than as subjects of sovereignty in the frame of each Korea's project to build a strong nation-state.

This shared dimension of peoplehood does not mean that its construction has only rested on consensus, neither between nor within the North and the South. On the contrary, the making and rewriting of their respective constitutions have been importantly premised on intra-, rather than inter-, Korean disagreements over whom the people is and who can speak in its name. Both countries' successive texts thus bear the marks of competing claims about peoplehood that their framers tried to silence, by incorporating or expunging them. While the former modus operandi was privileged by the northern and southern regimes in 1948 given the imperative of establishing a broad base of support to which the two were confronted, the latter technique enabled each Korea to significantly reshape its body politic over time. By the early 1970s, the theoretical inclusiveness originally attached to inmin in the discourse of the DPRK had thus given way to peoplehood's redefinition in terms of class, relegating those not falling within its new contours to the subordinate status of kongmin or citizens.

138. For an analysis of how minjung groups, in the face of post-1987 state repression, came to invest constitutional justice as an arena where to contest the contours of South Korea's democratic order, and for a detailed examination of the ambivalence with which the Constitutional Court of Korea has responded to this demand, see Guichard, supra note 75 . 
The pervasive insistence on both groups' belonging to the same family was correlatively strengthened to convey the maximalist demands of unity and loyalty associated with membership in the community of North Korean subjects. In the ROK, the struggle for and advent of democratization produced alternatives to kungmin that have failed, however, to fully subvert it as exemplified by the marginalization of the minjung movement's voice from the post-authoritarian constitutional order designed in 1987.

While people building is an activity that can unfold in a variety of sites, many of which may be deemed more relevant than the apparently remote and irenic realm of constitution making, the latter is precisely not as free of strife as suggested at first sight by its own textuality. By pretending to emanate from the people whose voice they transcribe, constitutions do not expose facts, but express claims. These claims are not only creative, but also contentious insofar as they construct the body politic's identity, rights, and duties against alternative possibilities, which can be articulated by competing actors as well as inscribed in predecessor documents. Beyond the cases of North and South Koreas examined and compared in this article, reading other constitutions in a similarly dynamic and sequential way may arguably provide a fruitful path to revisit conventional accounts about them, unearthing the conflict(s) rather than concord over constituting the people upon which fundamental-in a legal and political sense-texts are based.

\section{REFERENCES}

\section{Primary Sources}

\section{In Korean}

The South Korean Ministry of Government Legislation (MOLEG) makes available original Korean versions of the texts on which this article relies:

- The texts adopted by the Provisional Government of the ROK can be consulted online at < http:// www.law.go.kr/lsSc.do?menuId=0\&subMenu $=3 \& q u e r y=$ 대한민국임시 $>$ (last accessed 8 April 2016).

- The texts adopted by the ROK can be consulted online at <http://www.law.go.kr/lsSc.do? menuId=0\&subMenu=2\&query=대한민민국헌법 $>$ (last accessed 8 April 2016).

- The texts adopted by the DPRK can be consulted online at < http://world.moleg.go.kr/KP/law/ 23273? astSeq $=582>$ (last accessed 8 April 2016).

- The original version of the National Security Act and its subsequent revisions can be consulted online at $<$ http://www.law.go.kr/lsSc.do?menuId=0\&p1 =\&subMenu=1\&nwYn=1\&section=\&tabNo=\&query= 국가보안법 > (last accessed 9 April 2016).

In addition, the 1 March 1919 Declaration of Independence can be consulted online at $<$ https://ko. wikisource.org/wiki/3. 1독립선언서> (last accessed 7 April 2016).

\section{In English}

Democratic People's Republic of Korea (DPRK) (1948) "Constitution [as promulgated on 8 September 1948]," in M. Fukushima (1975) On the Socialist Constitution of the Democratic People's Republic of Korea, Pyongyang: Foreign Languages Publishing House, 283-99.

Democratic People's Republic of Korea (DPRK) (1972) "Socialist Constitution [as promulgated on 27 December 1972]," in M. Fukushima (1975) On the Socialist Constitution of the Democratic People's Republic of Korea, Pyongyang: Foreign Languages Publishing House, $53-80$. 
Democratic People's Republic of Korea (DPRK) (1993) Socialist Constitution [as amended on 9 April 1992], Pyongyang: Foreign Languages Publishing House.

Democratic People's Republic of Korea (DPRK) (1998) Socialist Constitution [as amended on 5 September 1998], HeinOnline World Constitutions Illustrated: Contemporary \& Historical Documents \& Resources.

Democratic People's Republic of Korea (DPRK) (2009) Socialist Constitution [as amended on 9 April 2009], HeinOnline World Constitutions Illustrated: Contemporary \& Historical Documents \& Resources.

Provisional Government of the Republic of Korea (1919a) "Aims and Aspirations of the New Korean Republic," in C.W. Kendall (1919) The Truth About Korea, San Francisco: The Korean National Association, 53-4.

Provisional Government of the Republic of Korea (1919b) "Provisional Constitution [as adopted on 11 April 1919]," in P. Lee et al., eds. (1996) Sourcebook of Korean Civilization, Volume II: From the Seventeenth Century to the Modern Period, New York: Columbia University Press, 435-6.

Republic of Korea (ROK) (1948) "Constitution [as promulgated on 17 July 1948]," in US Department of State (1950) Korea, 1945 to 1948: A Report on Political Developments and Economic Resources with Selected Documents, Washington, DC: US Government Printing Office, 78-95.

Republic of Korea (ROK) (1952) Constitution [as amended on 7 July 1952], Seoul: Office of Public Information.

Republic of Korea (ROK) (1955) Constitution [as amended on 29 November 1954], Seoul: Office of Public Information.

Republic of Korea (ROK) (1964) Constitution [as amended on 26 December 1962], Election and Political Party Laws, Seoul: Central Election Management Committee.

Republic of Korea (ROK) (1973) Constitution [as amended on 27 December 1972], Seoul: Overseas Information Service.

Republic of Korea (ROK) (1981) Constitution [as amended on 27 October 1980], Seoul: Overseas Information Service.

Republic of Korea (ROK) (1988) Constitution [as amended on 29 October 1987], Seoul: Constitutional Court of Korea.

\section{Works Cited}

Armstrong, Charles (2003) The North Korean Revolution, 1945-1950, Ithaca: Cornell University Press.

Cho, Jung-Kwan (2004) "The Politics of Constitution-Making during the 1987 Democratic Transition in South Korea." 35 Korea Observer 171-206.

Choi, Jang-Jip (1993) "Political Cleavages in South Korea," in H. Koo, ed., State and Society in Contemporary Korea, Ithaca: Cornell University Press, 13-50.

Choi, Jang-Jip (2012) Democracy after Democratization: The Korean Experience, Stanford: Walter H. Shorenstein Asia-Pacific Research Center.

Chung, Erin Aeran (2009) "The Politics of Contingent Citizenship: Korean Political Engagement in Japan and the United States," in S. Ryang \& J. Lie, eds., Diaspora without Homeland: Being Korean in Japan, Berkeley: University of California Press, 147-67.

Constitutional Court of Korea (2008) Twenty Years of the Constitutional Court of Korea, Seoul: Constitutional Court of Korea.

Cumings, Bruce (1981) The Origins of the Korean War, Volume I: Liberation and the Emergence of Separate Regimes, 1945-1947, Princeton: Princeton University Press.

Dutoya, Virginie, \& Samuel Hayat (2016) "Prétendre représenter: La construction sociale de la représentation politique." 66 Revue française de science politique 7-25.

Elster, Jon (2012) "Constitution-Making and Violence." 4 Journal of Legal Analysis 7-39.

Em, Henry (1993) “'Overcoming' Korea's Division: Narrative Strategies in Recent South Korean Historiography." 1 Positions: East Asia Cultures Critique 450-85. 
Em, Henry (2013) The Great Enterprise: Sovereignty and Historiography in Modern Korea, Durham: Duke University Press.

Fukushima, Masao (1975) On the Socialist Constitution of the Democratic People's Republic of Korea, Pyongyang: Foreign Languages Publishing House.

Ginsburg, Tom, \& Alberto Simpser (2014) "Introduction: Constitutions in Authoritarian Regimes," in T. Ginsburg \& A. Simpser, eds., Constitutions in Authoritarian Regimes, New York: Cambridge University Press, $1-15$.

Guichard, Justine (2016) Regime Transition and the Judicial Politics of Enmity: Democratic Inclusion and Exclusion in South Korean Constitutional Justice, New York: Palgrave Macmillan.

Hahm, Chaihark, \& Sung Ho Kim (2010) "To Make 'We the People': Constitutional Founding in Postwar Japan and South Korea." 8 International Journal of Constitutional Law $800-48$.

Hahm, Chaihark, \& Sung Ho Kim (2015) Making We the People: Democratic Constitutional Founding in Postwar Japan and South Korea, New York: Cambridge University Press.

Henderson, Gregory (1991) "Human Rights in South Korea, 1945-1953," in W. Shaw, ed., Human Rights in Korea: Historical and Policy Perspectives, Cambridge, MA: Harvard University Press, 125-69.

Hirschl, Ran (2009) "The Realist Turn in Comparative Constitutional Politics." 62 Political Research Quarterly 825-33.

Kihl, Young Whan (1988) "South Korea's Search for a New Order: An Overview," in I. Kim \& Y.W. Kihl, eds., Political Change in South Korea, New York: Paragon House, 3-21.

Kim, Chin (1972a) "North Korean Nationality Law." 6 The International Lawyer 324-9.

Kim, Il-sung (1972b) "Let Us Further Strengthen the Socialist System of Our Country," in M. Fukushima (1975) On the Socialist Constitution of the Democratic People's Republic of Korea, Pyongyang: Foreign Languages Publishing House, 1-49.

Kim, Ku (2000) The Autobiography of Kim Ku (Translated, Annotated and Introduced by Jongsoo Lee), Lanham: University Press of America.

Kim, Sŏng-bo (2009) "Nambuk kukka suripki inminkwa kungmin kaenyŏmŭi punhwa" ["Differentiation of the Concept of People during the Establishments of South and North Korea"]. 144 Hanguksa Yŏngu [Journal of Korean History] 69-95.

Lankov, Andrei (2005) "Soviet Politburo Decisions and the Emergence of the North Korean State, 1946-1948." 36 Korea Observer 385-404.

Lee, Chulwoo (2015) "The Law and Politics of Citizenship in Divided Korea." 6 Yonsei Law Journal 3-31.

Lee, Jung-Eun (2013) "Categorical Threat and Protest Policing: Patterns of Repression Before and After Democratic Transition in South Korea." 43 Journal of Contemporary Asia 475-96.

Lee, Namhee (2002) "Anticommunism, North Korea, and Human Rights in South Korea: 'Orientalist' Discourse and Construction of South Korean Identity," in M.P. Bradley \& P. Petro, eds., Truth Claims: Representation and Human Rights, New Brunswick: Rutgers University Press, 43-71.

Lee, Namhee (2007a) The Making of Minjung: Democracy and the Politics of Representation in South Korea, Ithaca: Cornell University Press.

Lee, Namhee (2007b) "The South Korean Student Movement: Undongkwŏn as a Counterpublic Sphere," in C. Armstrong, ed., Korean Society: Civil Society, Democracy, and the State, London: Routledge, 132-64.

Lee, Namhee (2011) "From Minjung to Simin: The Discursive Shift in Korean Social Movements," in G. Shin \& P. Chang, eds., South Korean Social Movements: From Democracy to Civil Society, New York: Routledge, 41-57.

Lee, Peter H., \& Wm. Theodore de Bary, with Yongho Ch'oe and Hugh H.W. Kang (1996) "The Nationalist Movement," in P. Lee \& Wm. Theodore de Bary, with Yongho Ch'oe and Hugh H.W. Kang, eds., Sourcebook of Korean Civilization, Volume II: From the Seventeenth Century to the Modern Period, New York: Columbia University Press, 428-31.

Loughlin, Martin, \& Neil Walker (2007) "Introduction," in M. Loughlin \& N. Walker, eds., The Paradox of Constitutionalism: Constituent Power and Constitutional Form, Oxford: Oxford University Press, $1-8$. 
Mengin, Françoise (2015) Fragments of an Unfinished War: Taiwanese Entrepreneurs and the Partition of China, London: Hurst \& Co.

Moon, Seungsook (2005) Militarized Modernity and Gendered Citizenship in South Korea, Durham: Duke University Press 2005.

Moon, Seungsook (2013) "The Idea and Practices of Citizenship in South Korea," in M. Pohlmann, J. Yang \& J. Lee, eds., Citizenship and Migration in the Era of Globalization: The Flow of Migrants and the Perception of Citizenship in Asia and Europe, Berlin: Springer, 9-38.

New York Times (1987) "Excerpts from Speech by Seoul Party Chief," 30 June.

NK News (2016) "N. Korea Updates Constitution Expanding Kim Jong Un's Position," 30 June.

Pak, Myŏng-gyu (2009) Kungmin, inmin, simin: kaenyŏmsaro pon han'gukŭi chŏngch'i chuch'e [Nationals, People, Citizens: Korea's Political Subject Seen through the History of Concepts], Seoul: Sohwa.

Park, Chung-hee (1972) "Address by Park Chung Hee on the Occasion of Announcing the Draft Amendments to the Constitution," in Republic of Korea (1973) Constitution, Seoul: Overseas Information Service, 27-9.

Park, Myung Lim (2011) "Constitution, National Agenda, and Presidential Leadership: Focusing on a Comparison Between the Articles on Economy in 'National Founding Constitution' and the 'Post-Korea War Constitution." 1 Korean Social Sciences Review 263-302.

Rancière, Jacques (1999) Disagreement: Politics and Philosophy, Minneapolis: University of Minnesota Press.

Robinson, Michael (2007) Korea's Twentieth-Century Odyssey: A Short History, Honolulu: University of Hawaii Press.

Ryang, Sonia (2009) "Between the Nations: Diaspora and Koreans in Japan," in S. Ryang \& J. Lie, eds., Diaspora without Homeland: Being Korean in Japan, Berkeley: University of California Press, $1-20$.

Saward, Michael (2006) "The Representative Claim." 5 Contemporary Political Theory 297-318.

Schmid, Andre (2002) Korea between Empires, 1895-1919, New York: Columbia University Press.

Shin, Gi-Wook (2006) Ethnic Nationalism in Korea: Genealogy, Politics, and Legacy, Stanford: Stanford University Press.

Shin, Jong-dae (2012) "DPRK Perspectives on Korean Reunification after the July 4th Joint Communiqué," in North Korea International Document Project, E-Dossier 10, Washington, DC: Woodrow Wilson International Center for Scholars, 1-3.

Sin, U-chŏl (2008) "Imsi hŏnjang (1944.4.22) yŏngu" ["Research on the 1944 Provisional Charter"]. 34 Pópkwa sahoe [Journal of Law and Society] 323-72.

Smith, Rogers (2015) Political Peoplehood: The Roles of Values, Interests, and Identities, Chicago: University of Chicago Press.

Sŏ, Hŭi-gyŏng (2012) Taehan min'guk hŏnpŏp t'ansaeng [The Birth of the Republic of Korea's Constitution], Seoul: Ch'angbi.

West, James (1997) "Martial Lawlessness: The Legal Aftermath of Kwangju." 6 Pacific Rim Law and Policy Journal 85-168.

Yi, Yŏng-nok (2006) Uri hŏnpŏpŭi t'ansaeng: hŏnp̆̌pŭro pon taehan min'guk kŏn'guksa [Our Constitution's Birth: The Founding History of the Republic of Korea Seen through Constitutional Law], P'aju: Sohae Munjip.

Yonhap (2012) "North Korea Calls Itself 'Nuclear-Armed State' in Revised Constitution," 30 May.

Yoon, Dae-Kyu (2003) "The Constitution of North Korea: Its Changes and Implications." 27 Fordham International Law Journal 1289-305.

Yoon, Dae-Kyu (2010) Law and Democracy in South Korea: Democratic Development since 1987, Seoul: Kyungnam University Press.

Yu, Xingzhong (2002) "Citizenship, Ideology, and the PRC Constitution," in M. Goldman \& E. Perry, eds., Changing Meanings of Citizenship in Modern China, Cambridge, MA: Harvard University Press, 288-307. 